\title{
Inside a Microapartment: Design Solutions to Support Future Sustainable Lifestyles
}

\author{
Barbara Ewa Gronostajska ${ }^{1, *}$ and Anna Szczegielniak ${ }^{2, *}$ \\ 1 Faculty of Architecture, Wroclaw University of Science and Technology, 27 Wybrzeze Wyspianskiego St., \\ 50-370 Wroclaw, Poland \\ 2 Faculty of Civil Engineering and Architecture, Opole University of Technology, ul. Prószkowska 76, \\ 45-758 Opole, Poland \\ * Correspondence: barbara.gronostajska@pwr.edu.pl (B.E.G.); a.szczegielniak@po.edu.pl (A.S.)
}

Citation: Gronostajska, B.E.; Szczegielniak, A. Inside a Microapartment: Design Solutions to Support Future Sustainable Lifestyles. Buildings 2021, 11, 654. https:// doi.org/10.3390/buildings11120654

Academic Editor: Audrius Banaitis

Received: 24 October 2021

Accepted: 10 December 2021

Published: 16 December 2021

Publisher's Note: MDPI stays neutral with regard to jurisdictional claims in published maps and institutional affiliations.

Copyright: (c) 2021 by the authors. Licensee MDPI, Basel, Switzerland. This article is an open access article distributed under the terms and conditions of the Creative Commons Attribution (CC BY) license (https:// creativecommons.org/licenses/by/ $4.0 /)$.

\begin{abstract}
The purpose of this study wass to assess the interior design solutions of residential microflats built in large European cities in countries from the Organisation for Economic Co-operation and Development (OECD). A sample consisting of thirty representative microflats with a floor area below $35 \mathrm{~m}^{2}$ was selected for the study. The flats were intended for either permanent or temporary occupancy and were built over the past fifteen years. The research field covered several large European cities, where demand for such units is high. Comparative analyses of different microflat interior design models were performed. The objective of the study was to determine which contemporary microflat interior design solutions (such as space layout, furniture layout, and design, color, and material design) are optimal and the most commonly used. Sets of design solutions applied in microflats were collected and documented. The study used a range of research methods, including a review of the literature, websites, field research, and comparative analysis. The set of presented interior design solutions and the conclusions drawn from the analyses can be useful to architects and interior designers who design microflats and residential units with greater floor areas, or flats where effective use of floor area is crucial (e.g., student housing). It is also worth mentioning that the existing literature on microflats focuses primarily on the United States and Australia and not Europe, and discusses the economics and ecology of inhabiting microflats.
\end{abstract}

Keywords: design phase analysis; new forms of housing; interior architecture; microapartment; compact living

\section{Introduction}

The twenty-first century is a period of dynamic effect changes in the design of the housing environment [1-3]. In recent years, there has been an observable and highly dynamic increase in interest in microhouses and microflats, which have slowly started being defined as a new form of housing $[2,4,5]$. This increase is primarily caused by two groups of factors: the first consists of economic factors, such as high housing prices [3], and the second are demographic and social factors. The demographic and societal changes that affect microflat popularity include:

- Changes in the family model-people are entering relationships later in life and families tend to have fewer children, which leads to an increase rise in the number of single-person households [1,3,5,6];

- $\quad$ The aging of society and a corresponding increase in the number of senior citizens [7] the elderly often live alone, in units that are too large for them [8]

- Changes in how residential spaces are used-certain needs that were previously satisfied in flats such as dining or entertainment have been moving outside, or to other spaces $[9,10]$. 
- Changes in flat furnishings-many elements of everyday interior furnishing have become smaller due to technological progress, e.g., flatscreen television sets, laptop computers, e-book readers, music, and photographs stored in digital form [3].

- Greater environmental awareness leads to more eco-friendly lifestyles [11] and attempts at reducing the number of possessions or the conservation of natural resources [12]

- The popularity and development of the so-called sharing economy, which favorably align itself with the idea of residential microspaces [10].

- New forms of living such as 'co-living' where often the private space is minimalized and complemented with shared space [13]

\subsection{Microflat-Definition}

Residential microspaces are a new phenomenon that is just beginning to be defined. In the literature, we can find many different definitions and classifications of terms that concern microflats. The term microapartment (also: micro-unit or microflat) can have a very broad meaning. Such a unit has no strictly defined size and is typically defined in the context of other units in a given place (country, region, city). This is why the sizes of European, American, or Asian microflats can differ considerably. Typically, a microflat is smaller than a standard single-room flat in a given area, and its size typically does not exceed 35-40 $\mathrm{m}^{2}$ [14]. Here we can see a correlation of this size with studies of minimum residential space conducted by Cohen [15]. This study concluded that a comfortable and safe space for a single person should be around $14-20 \mathrm{~m}^{2}$, and for four persons it should be around $42-80 \mathrm{~m}^{2}$.

Independence is also crucial-a microflat is an independent unit, with its own entrance, has a dedicated space for living/sleeping, and a bathroom and place to cook (a kitchenette) [10].

In this study, we assumed the following definition of a microflat-a flat that has a floor area lower than $35 \mathrm{~m}^{2}$, is independent, self-sufficient, used in various ways (it can be used as a temporary residence), located in a large city and equipped in a manner that allows living comfortably on a small area. This study investigates the furnishing of such a flat.

This paper has the following structure. In the introduction, defines the term 'microflat', documents the previous literature on microflats, and defines the objective of the study. The following section presents the sample selection criteria, the research method, and the categories of arrangement solutions that were used to analyze the selected microflats. The final section documents the findings of the analysis and presents an attempt at explaining them.

\subsection{Literature Review}

Previous studies on microflats identified the users of such spaces. They are typically:

- Persons who live alone or couples [6,16];

- People who spend a lot of time outside the home and believe that the city is an extension of their flat [10];

- Persons forced to change their place of residence because of a divorce [3];

- Senior citizens;

- Seasonal workers [16];

- People are inclined to limit the number of their possessions and to use the so-called sharing economy, e.g., they do not own cars but use car-sharing services [10].

Buildings with microflats are often complemented with additional common spaces such as living rooms, dining rooms, and co-working spaces [10], as well as areas that enhance the comfort of living, such as patios, rooftop terraces, and lobby-type or reception spaces in the ground-floors [3]

Microflats can be eco-friendly as they need less energy and resources to build, maintain, cool, or heat. Their siting in city centers means that the residents of such spaces often forgo the use of cars in favor of walking or using public transport $[3,5,10,17]$. Microflats have a positive impact on reducing urban sprawl as they enable denser development in 
central areas $[5,10,16]$. Unfortunately, due to their extremely small floor areas, microflats can generate a range of threats. The threats that have been documented in the literature include physiological ones-associated with the need to fold furniture-or psychological ones-linked to the overcrowding in a small space $[18,19]$.

Studies on motivations behind choosing microflats for a home point to the main reasons for doing so being the lower price of such units, the possibility of living alone $[3,10,20]$, and a good location, typically in a downtown area [20]. Many scholars highlighted the maladaptation of contemporary construction codes to development that includes microflats. Barriers that hinder the construction of such forms of housing include requirements concerning the minimum number of parking spaces, the size of external spaces, the size of common spaces, or minimum residential unit floor area values [3,10,16,21].

In terms of studying the interiors of microflats, an interesting aspect was investigated by Fisher-Gewirtzman [22], who explored the perception of space in small flats. In her study, Fisher-Gewirtzman used elements of virtual reality, proving that a small apartment is perceived by its residents as larger if one can see a window from the side of the entrance, and as more private when the bed is on a mezzanine. In a second study from 2017 [23], it was observed that apartments with windows placed opposite the entrance and with a place to sleep on a mezzanine are perceived as larger (the introduction of natural light and expansion of the view). The units perceived as the smallest were divided into many small spaces, with a blocked view of the window.

A link between good well-being in microflats and their furnishing has also been observed [24]. According to Thøgersen, furniture in microflats should be adapted to user needs, be custom-made, provide room for personalization, be simple to use, provide an illusion of greater space, it should not clutter the space, and be light and moveable.

\subsection{Research Aim}

This paper aims to supplement the research gap identified in the literature review by presenting an analysis of microflat interior design. The main purpose is to investigate the current interior design of microflats and assess their functionality and program. The detailed objectives of the study were: (1) to isolate and systematize microflat design methods, and (2) to define the common traits and differences between microflat designs of varying size and designed for different users.

To perform the analysis, we selected designs by renowned architectural firms that were awarded prizes, published in the trade press, and placed on websites. The collected arrangement and design solutions are a set of good practices in microflat design and can serve as an application basis that could prove useful in the first phase of the design process. Such a set could be used by design specialists (architects, interior designers), as well as the residents of such spaces.

\section{Materials and Methods}

\subsection{Materials}

The objects chosen for investigation were microflats located in different large European cities in countries from the Organisation for Economic Co-operation and Development (OECD), which were built over the past fifteen years (2005-2020). We decided to confine the selection of cities to the two largest groups defined by the OECD as functional urban areas (FUA) - large metropolitan areas (with populations above 1.5 million) and metropolitan areas (with populations between 250,000 and 1.5 million) [25]. We chose high-quality cases that received prizes and were reported on in architectural trade magazines and by trade websites. Following the previously adopted microflat definitions, we chose microflats that were independent (had their own entrance) and self-sufficient (had a living/sleeping space and a bathroom and kitchen/kitchenette). The maximum floor area for the cases was assumed at $35 \mathrm{~m}^{2}$. No minimum floor area value was assumed. The price criterion, although very important, was not included in this study due to the lack of availability of such data. However, because the examined projects were made by professional architectural offices, 
often awarded and published in the architectural press, it can be concluded that these are generally luxury apartments, being a place of residence by choice and not by necessity.

After an initial analysis of the microflats, we proposed an original division of the cases under study into three size groups:

- S-floor area between 35 and $25 \mathrm{~m}^{2}$ (typical flats with a separate sleeping area);

- XS-floor area between 25 and $15 \mathrm{~m}^{2}$ (single-space flats);

- XXS-floor area lower than $15 \mathrm{~m}^{2}$ (extremely small units).

There were over 100 microflats preliminary studied. Then the 30 (10 in each group), that met the assumed conditions (size, location, time of realization), were selected for further study. All selected apartments were selected based on the designs of architectural studios. However, in some cases, the best information was obtained from websites such as ArchDaily (https:/ /www.archdaily.com/, accessed on 18 December 2020), DesignMilk (https:/ / design-milk.com/, accessed on 20 December 2020) or DeZeen (https://www. dezeen.com/, accessed on 20 December 2020) collecting and presenting current projects of various architects (Tables 1 and A1).

Table 1. The list of the analyzed microapartments with basic information.

\begin{tabular}{|c|c|c|c|c|}
\hline No. & Name & Architect & Location & Year \\
\hline \multicolumn{5}{|c|}{$\operatorname{M.S}\left(25-35 \mathrm{~m}^{2}\right)$} \\
\hline M.S.1 & Geneva Flat & FREAKS architects & Geneva, $\mathrm{CH}$ & 2014 \\
\hline M.S.2 & Apartment $\mathrm{C}$ & SCHEMAA & Paris, FR & 2014 \\
\hline M.S.3 & $30 \mathrm{~m}^{2}$ flat in Paris & Richard Guilbault & Paris, FR & 2015 \\
\hline M.S.4 & Casa Da Porteira & AF Arquitectos & Lisboa, PT & 2015 \\
\hline M.S.5 & Długi Lokal & Mili Młodzi Ludzie & Poznań, PL & 2014 \\
\hline M.S.6 & $100 \mathrm{~m}^{3}$ & MYCC & Madrid, ES & 2012 \\
\hline M.S.7 & 29 SQM & Czerny Design & Wrocław, PL & 2012 \\
\hline M.S.8 & Batipin Flat & Studio Wok & Milano, IT & 2015 \\
\hline M.S.9 & Air B'n'P & POSITION Collective & Budapest, HU & 2015 \\
\hline M.S.10 & Mieszkanie Piotra & Mili Młodzi Ludzie & Poznań, PL & 2013 \\
\hline \multicolumn{5}{|c|}{ M.XS $\left(15-25 \mathrm{~m}^{2}\right)$} \\
\hline M.XS.1 & Biombombastic & Elii & Madrid, ES & 2015 \\
\hline M.XS.2 & Studio Li & Anne Rolland Architecture & Paris, FR & 2014 \\
\hline M.XS.3 & Mieszkanie na Tamce & Jakub Szczęsny & Warsaw, PL & 2009 \\
\hline M.XS.4 & Microapartment Moabit & Paola Bagna, John Paul Coss & Berlin, DE & 2015 \\
\hline M.XS.5 & Apartment Spectral & Betillon, Dorval Bory & Paris, FR & 2013 \\
\hline M.XS.6 & Studio $18.9 \mathrm{~m}^{2}$ & Konrad Urbanowicz & Wrocław, PL & 2016 \\
\hline M.XS.7 & Apartment $\mathrm{AB}$ & AB Rogers Design & London, UK & 2017 \\
\hline M.XS.8 & Sophia Apartment & BlackHaus & Cracow, PL & 2017 \\
\hline M.XS.9 & Sato StudioKoti & Innovarch & Helsinki (Vantaa) FI & 2017 \\
\hline M.XS.10 & $\begin{array}{l}\text { Hermes City Plaza } \\
\text { Student Housing }\end{array}$ & Standard Studio & Rotterdam, NL & 2017 \\
\hline \multicolumn{5}{|c|}{ M.XXS $\left(<15 \mathrm{~m}^{2}\right)$} \\
\hline M.XXS.1 & Bien Vivre Dans & $\begin{array}{l}\text { Julie Nabucet, } \\
\text { Marc Baillargeon }\end{array}$ & Paris, FR & 2011 \\
\hline M.XXS.2 & $\begin{array}{l}\text { Romain, } \\
\text { Paris Attic studio }\end{array}$ & Batiik Studio & Paris, FR & 2016 \\
\hline M.XXS.3 & Boulevard Malesherbes & Sylvie Cahen & Paris, FR & 2006 \\
\hline M.XXS.4 & $13 \mathrm{~m}^{2}$ & Szymon Hanczar & Wrocław, PL & 2014 \\
\hline M.XXS.5 & Apt. 911, Starter I & AP Szczepaniak & Wrocław, PL & 2013 \\
\hline M.XXS.6 & Rue Lourmel & Sylvie Cahen & Paris, FR & 2016 \\
\hline M.XXS.7 & Rue Des Canettes & Sylvie Cahen & Paris, FR & 2010 \\
\hline M.XXS.8 & The Lux Pod & Studio Bednarski & London, UK & 2010 \\
\hline M.XXS.9 & Tiny apartament in Paris & Kitoko Studios & Paris, FR & 2014 \\
\hline M.XXS.10 & La Casa Piu Piccola di Italia & Marco Pierazzi & Rome, IT & 2010 \\
\hline
\end{tabular}

\subsection{Methods}

The following research methods were applied: in order to collect a research material a review of the literature (queries, research of direct and indirect sources, review of digital libraries, electronic databases, and websites) and field research (site visits, photographic 
and descriptive documentation, interviews) were done. The analysis of the research material was carried out on the basis of diagnostic and prognostic methods, a multiple-case study [26], and a comparative analysis of selected cases. The microflats were investigated based on descriptions and iconographic materials (design drawings, floor plans, crosssections, axonometric projections, diagrams, photographs) available either in the literature or online, on the websites of the designers of specific units, and on-site investigation. To exhaustively explore the subject of microflat interior design, we chose a relatively extensive study group (30 units) in a variety of geographical locations (14 large cities from European OECD member states).

In the study presented, we analyzed microflats in terms of their functional layout, interior composition, and interior design methods applied. We collected essential data about the units in tables, listing: floor area, volume, residential area, ancillary area, number of levels that feature residential functions, user number, presence, and size of external space (Table 2).

Table 2. Microapartments—size and dimensions.

\begin{tabular}{|c|c|c|c|c|c|c|c|c|}
\hline No. & Area $\left[\mathrm{m}^{2}\right]$ & $\begin{array}{l}\text { Volume } \\
{\left[\mathrm{m}^{3}\right]}\end{array}$ & $\underset{\text { Space }\left[\mathrm{m}^{2}\right]}{\text { Living }}$ & $\begin{array}{c}\text { Ancillary } \\
\text { Space }\left[\mathrm{m}^{2}\right]\end{array}$ & $\begin{array}{c}\text { Share of Residential } \\
\text { Space in Total } \\
\text { Floor Area }\end{array}$ & No. of Users & $\begin{array}{l}\text { Usable Space per } \\
1 \text { Person }\left[\mathrm{m}^{2}\right]\end{array}$ & $\begin{array}{c}\text { Outside Space, Type, } \\
\text { and Area }\left[\mathrm{m}^{2}\right]\end{array}$ \\
\hline \multicolumn{9}{|c|}{$\mathrm{S}\left(25-35 \mathrm{~m}^{2}\right)$} \\
\hline M.S.1 & 35.3 & 100.3 & 27.8 & 7.5 & $78.9 \%$ & 1 & 35.3 & balcony 1.5 \\
\hline M.S. 2 & 32.8 & 112.6 & 22.4 & 10.4 & $68.3 \%$ & $1-2$ & $16.4-32.8$ & - \\
\hline M.S.3 & 31.7 & 83.0 & 26.2 & 5.5 & $82.6 \%$ & 2 & 15.85 & - \\
\hline M.S. 4 & 30.3 & 89.7 & 22.6 & 7.7 & $74.6 \%$ & $1-2$ & $15.1-30.3$ & terrace \\
\hline M.S. 5 & 29.9 & nd & 25.0 & 4.9 & $83.6 \%$ & 2 & 14.95 & - \\
\hline M.S.6 & 29.4 & 100.0 & 18.3 & 11.1 & $62.2 \%$ & $\overline{1}$ & 29.4 & - \\
\hline M.S.7 & 28.8 & 106.6 & 22.0 & 6.8 & $76.4 \%$ & $1-2$ & $14.4-28.8$ & - \\
\hline M.S.8 & 28.6 & 82.8 & 20.2 & 8.4 & $70.6 \%$ & 2 & 14.3 & loggia 5.05 \\
\hline M.S.9 & 27.5 & 96.2 & 19.9 & 7.6 & $72.4 \%$ & 2 & 13.75 & loggia 1.41 \\
\hline M.S.10 & 26.4 & 83.5 & 23.2 & 3.2 & $87.9 \%$ & 1 & 26.4 & - \\
\hline \multicolumn{9}{|c|}{$\mathrm{XS}\left(15-25 \mathrm{~m}^{2}\right)$} \\
\hline M.XS.1 & 24.9 & 63.7 & 22.1 & 2.8 & $88.6 \%$ & 1 & 24.9 & - \\
\hline M.XS.2 & 23.4 & 71.8 & 19.9 & 3.5 & $85.0 \%$ & $1-2$ & $11.7-23.4$ & - \\
\hline M.XS.3 & 21.4 & 58.3 & 18.0 & 3.4 & $84.1 \%$ & 2 & 10.7 & - \\
\hline M.XS.4 & 20.8 & 66.8 & 11.2 & 9.6 & $53.8 \%$ & 2 & 10.4 & - \\
\hline M.XS.5 & 20.0 & 62.8 & 11.1 & 8.9 & $55.4 \%$ & $1-2$ & $10.0-20.0$ & - \\
\hline M.XS.6 & 18.9 & 58.7 & 12.4 & 6.5 & $65.4 \%$ & $1-2$ & $9.45-18.9$ & - \\
\hline M.XS.7 & 18.7 & 61.7 & 11.1 & 7.6 & $59.3 \%$ & $1-2$ & $9.35-18.7$ & - \\
\hline M.XS.8 & 18.5 & 64.0 & 13.5 & 5.0 & $72.9 \%$ & 1 & 18.5 & - \\
\hline M.XS.9 & 18.2 & 72.8 & 11.9 & 6.3 & $65.4 \%$ & $1-2$ & $9.1-18.2$ & balcony 2.0 \\
\hline M.XS.10 & 15.6 & 46.0 & 10.8 & 4.8 & $69.1 \%$ & 1 & 15.6 & - \\
\hline \multicolumn{9}{|c|}{$\mathrm{XXS}\left(<15 \mathrm{~m}^{2}\right)$} \\
\hline M.XXS.1 & 15.4 & 37.8 & 6.9 & 8.5 & $44.6 \%$ & $1-2$ & $7.7-15.4$ & - \\
\hline M.XXS.2 & 15.3 & 51.4 & 8.7 & 6.6 & $56.9 \%$ & $1-2$ & $7.65-15.3$ & - \\
\hline M.XXS.3 & 13.2 & 45.9 & 7.8 & 5.4 & $58.9 \%$ & $1-2$ & $6.6-13.2$ & - \\
\hline M.XXS.4 & 13.0 & 43.3 & 9.3 & 3.7 & $71.4 \%$ & 1 & 13 & - \\
\hline M.XXS.5 & 12.9 & 34.5 & 8.4 & 4.5 & $64.8 \%$ & 1 & 12.9 & - \\
\hline M.XXS.6 & 11.9 & 44.7 & 8.6 & 3.4 & $71.7 \%$ & 2 & $5.95-11.9$ & - \\
\hline M.XXS.7 & 9.5 & 37.5 & 5.6 & 3.9 & $58.9 \%$ & 1 & 9.5 & - \\
\hline M.XXS.8 & 9.4 & 26.0 & 7.0 & 2.4 & $74.3 \%$ & $1-2$ & $4.7-9.4$ & - \\
\hline M.XXS.9 & 7.6 & 20.2 & 6.3 & 1.3 & $82.7 \%$ & 1 & 7.6 & - \\
\hline M.XXS.10 & 6.3 & 21.7 & 4.9 & 1.4 & $77.1 \%$ & $1-2$ & $3.15-6.3$ & - \\
\hline
\end{tabular}

* Ancillary spaces include rooms that, when at least partially sectioned off, not necessarily with walls, act solely in an ancillary manner. For instance, ancillary spaces do not include kitchens with dining rooms and places to sit or larger spaces that fulfill various functions, including that of a kitchen or wardrobe.

Based on our personal design experience, the observation of existing architectural solutions, and analyses of the literature [27-31], we formulated a reference list of solutions with which one can design and arrange a minimum residential area.

The process of interior design can vary greatly and can depend on both the architect and the user. The model of activity (design phases) is presented in the diagram in Figure 1. 


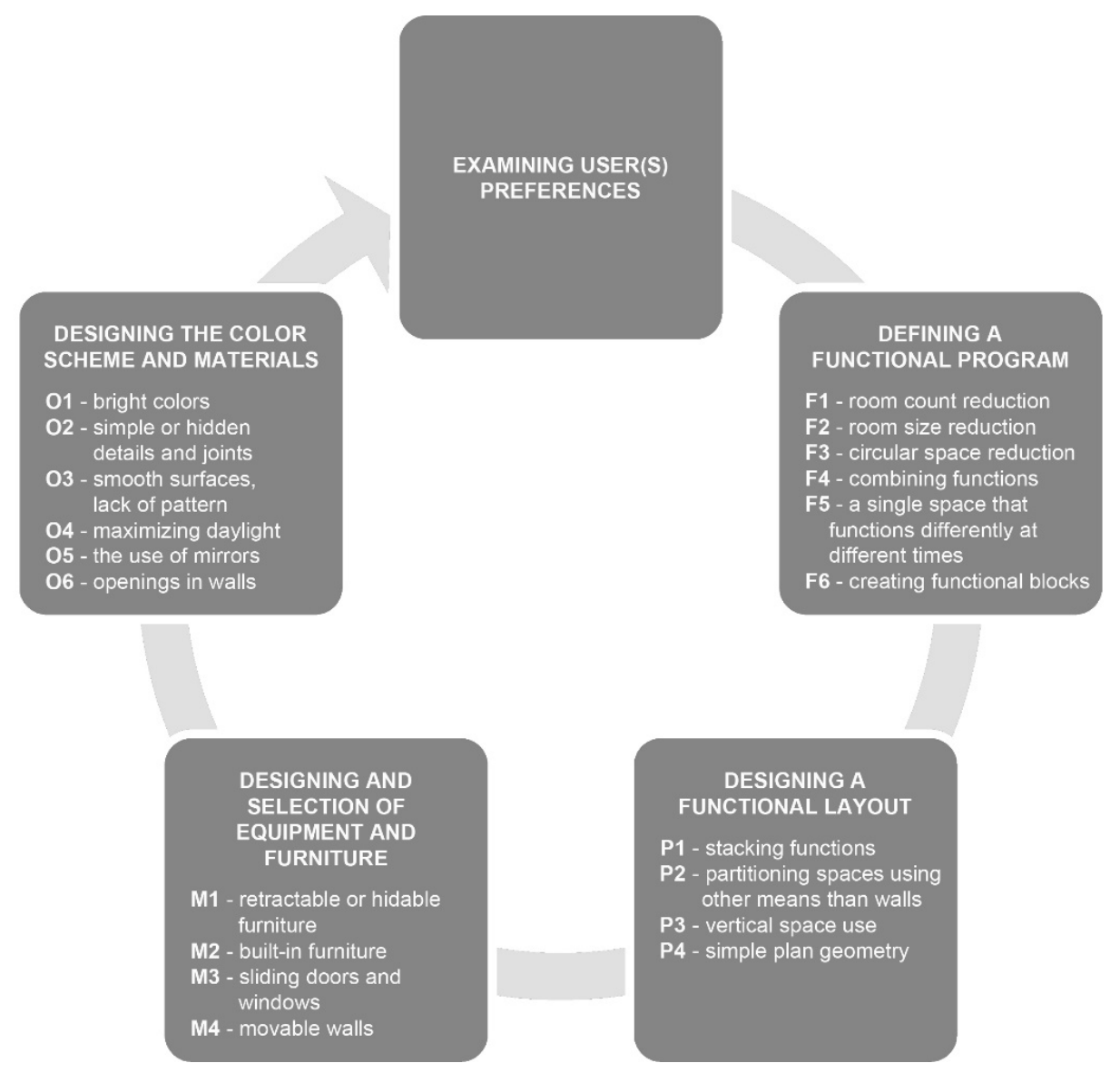

Figure 1. Model of activity/design phases.

The individual tasks (phases) sometimes overlap or there can be a return to initial tasks, which is why the scheme has an iterative character. In reference to the interior design phases, the architectural solutions applied in microflats were divided into four categories, depending on the design means used and when they can be used during the design process: $\mathrm{F}$-functional solutions, $\mathrm{P}$ - spatial solutions, $\mathrm{M}$ - furniture and interior design solutions, $\mathrm{O}-$ optical solutions.

\subsection{F-Functional Solutions}

Solutions from this group apply to a unit's functional program. These are decisions that must typically be made early, during the pre-design stage, which is when all types of changes and corrections can be made. Such solutions are typically applied in new constructions or general renovations and are rare in adaptive reuse projects.

Below is an overview of changes in functional solutions:

- $\quad$ F1-room count reduction-deciding not to section off certain functions, e.g., the lack of a dedicated dining room, no full kitchen (a solution for persons who eat outside the home));

- F2-room size-reduction-designing space with the minimum possible floor area, dictated by ergonomics or the size of furniture/appliances, which have to be installed in a given space, e.g., a bedroom designed as a bed-sized niche for sleeping;

- F3-circulation space reduction (circulation space is provided by parts of spaces with other functions, e.g., crossing from one space to another via a different space, no dedicated vestibule, hallway, etc.);

- F4-combining functions, multi-purpose rooms, with no wall divisions-one space can feature zones with different functions, e.g., combining a kitchen with a dining area, a kitchen with a dining area and living area, etc. 
- $\quad$ F5-a single space that functions differently at different times-depending on furniture layout, partition setting, and interior rearrangement, can fulfill various functions (contrary to F4, here there is rearrangement, i.e., furniture is moved, hidden and retractable furniture is opened, etc.);

- $\quad$ F6 - creating functional blocks (combining elements with similar functions into blocks and placing them nearby or together, to free up space).

\subsection{P-Spatial Solutions}

Design solutions from this group concern the dimensions and shape of the unit or room and are typically used during building design. It is difficult to apply them to existing buildings, where room dimensions and shapes have already been defined.

The following spatial solutions in the design of residential microspaces were identified:

- P1—stacking functions-the use of a room's height, introducing a mezzanine or additional story so as to add another function, e.g., a bedroom on a mezzanine, above a bathroom or kitchen;

- $\quad$ P2-not building walls—-partitioning spaces using other means than walls, e.g., using furniture, stairs, an openwork screen, the space's shape, a local widening/narrowing of space, a lowering of the ceiling, etc.;

- P3-vertical space use-for instance by using furniture that extends along with the entire height of a wall, the use of space under the stairs, the bed, etc. This solution differs from P1 in that functions are not stacked on top of each other (e.g., a bedroom above a bathroom), but merely occupy the space in the upper parts of walls for shelving, storage spaces, etc. or occupy the space under other interior furnishing elements (under the stairs, the bed, etc.);

- P4-simple plan geometry-interiors are designed to have simple floor plans, e.g., in the shape of a rectangle or square, without acute angles, corners, etc.

\subsection{M-Furniture/Equipment Solutions}

Furniture and equipment solutions are based on using items such as furniture, windows, doors, divisions between spaces. Solutions from this group can be applied both in newly designed buildings and in adaptive reuse projects.

The following furniture and equipment methods of designing minimum residential spaces were identified:

- M1—the design of retractable or hidable furniture-furniture whose elements can be hidden or that change their geometry;

- $\quad$ M2-using built-in furniture (furniture built into a wall or that form a partition between spaces themselves, e.g., kitchen furniture or built-in wardrobes);

- M3-the use of sliding doors or windows;

- M4-the design of movable walls that can change the shape of the space, or either combine or separate neighboring spaces.

\subsection{O-Optical Solutions}

Optical solutions are a group of solutions that are the cheapest and easiest to apply, and which are independent of the architecture of a given building or interior. They can be applied both in newly designed buildings and in adaptive reuse projects. Optical solutions concern the apparent impression of a space's size, associated with, among others, color or wall patterns. Such solutions do not change the size of spaces but provide a visual impression of either a small or large space.

The following optical means of designing minimal residential spaces were identified:

- O1-using bright colors;

- $\quad$ O2 - designing simple or hidden details and joints—retractable handles, knobs, simple connections between elements that produce an impression of visual calmness and order;

- $\quad$ O3-using smooth surfaces, a lack of patterns; 
- $\quad$ O4-maximizing daylight - the best possible use of means of admitting daylight, not a space- - e.g., by placing functions that require greater insolation near windows (in existing buildings), or the design of very large glazing and windows (in existing buildings adapted into microflats), the use of transparent partitions between spaces, etc.

- $\quad$ O5-the use of mirrors or reflective surfaces;

- O6-introducing openings in walls between spaces (so that we can see a different space while being in another).

The interiors of the studied objects were carefully analyzed in terms of the occurrence of solutions from each of the groups. The occurrence of a given method of designing residential micro-spaces in the examined facilities is marked in Tables A2-A5.

\section{Results}

The analysis of the microspaces and their arrangement enabled the grouping of each arrangement solution in terms of frequency of use (Figures 2-5).

\subsection{M.S}

The solutions that were the most popular in the M.S group were spatial ones (P). Among spatial solutions (P), those most frequently used were based on using space vertically (P3) - space under the stairs and the bed was used for storage.

Functional solutions (F) were also popular, including reducing room numbers (F1) or sizes (F3), as well as reducing circulation spaces (F3) and combining functions (F4), in addition to optical solutions $(\mathrm{O})$. In the case of combining functions, it was the most common to form multifunctional living rooms combined with kitchens and dining spaces, with the addition of sleeping spaces being less common. From among optical solutions $(\mathrm{O})$, popular ones included attention to the optimal use of daylight $(\mathrm{O} 4)$, the application of furnishings with simple details $(\mathrm{O} 2)$, bright surfaces $(\mathrm{O} 1)$, and smooth surfaces with no patterns (O3).

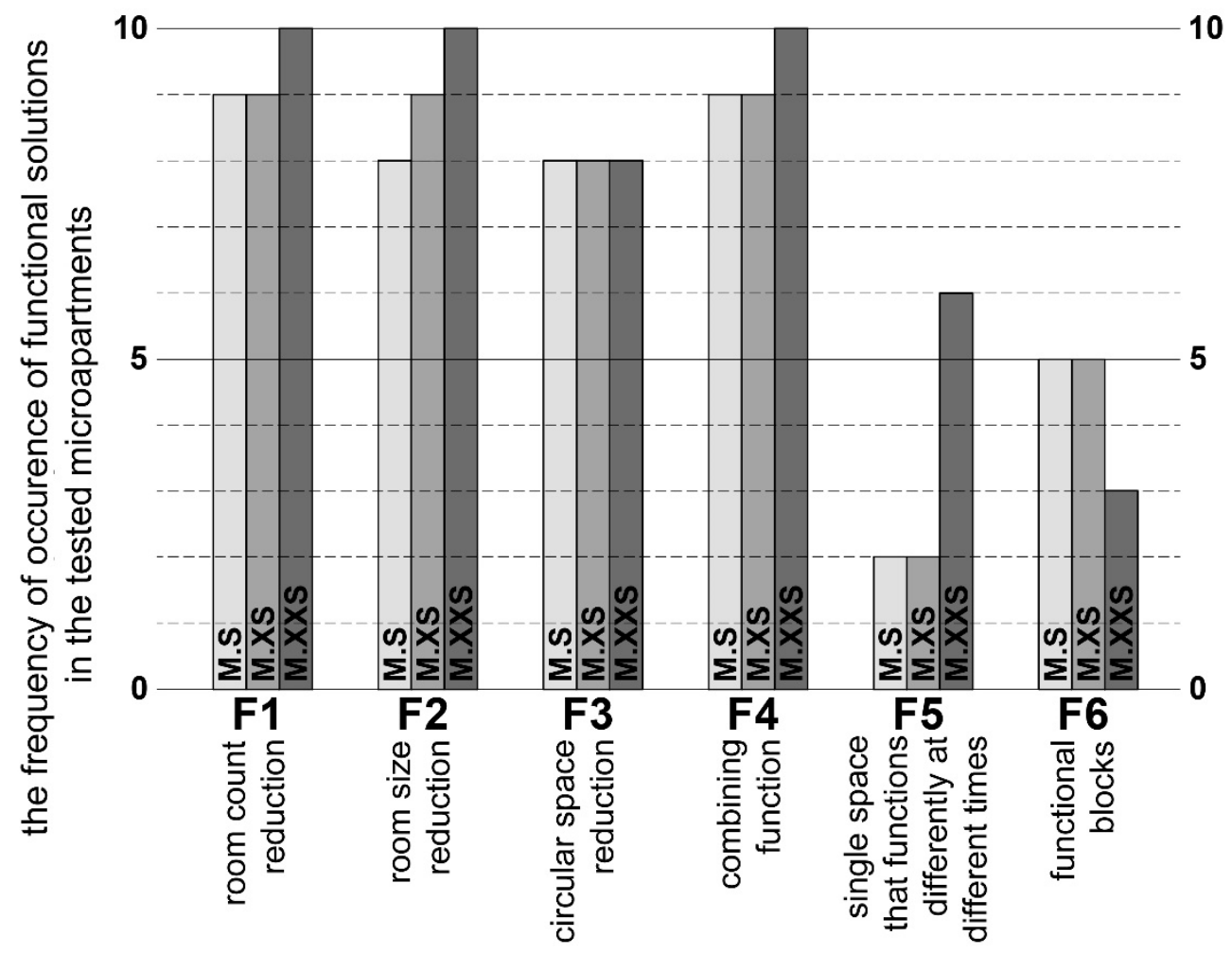

Figure 2. The frequency of occurrence of functional solutions in the tested microapartments. 


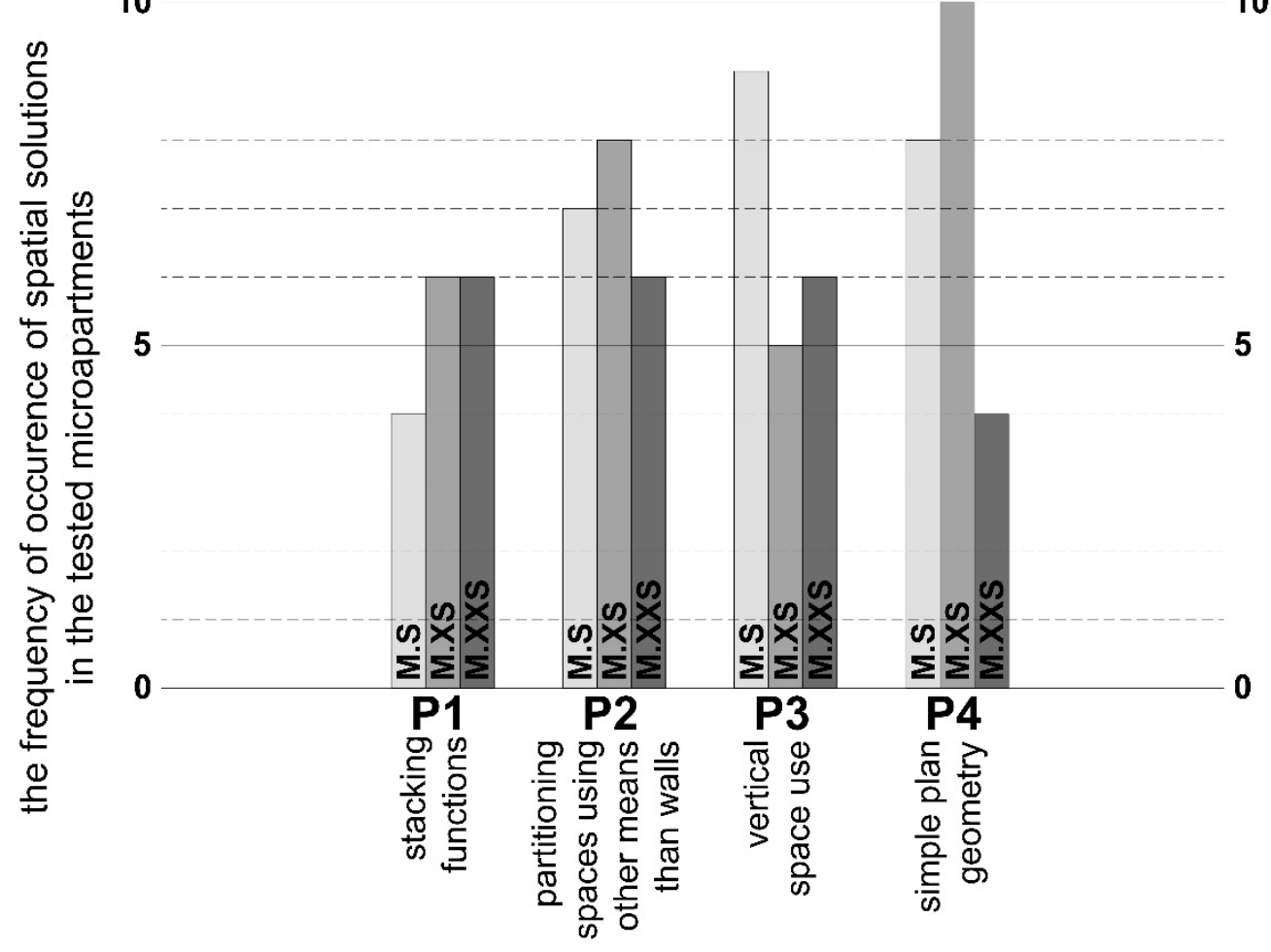

Figure 3. The frequency of occurrence of spatial solutions in the tested microapartments.

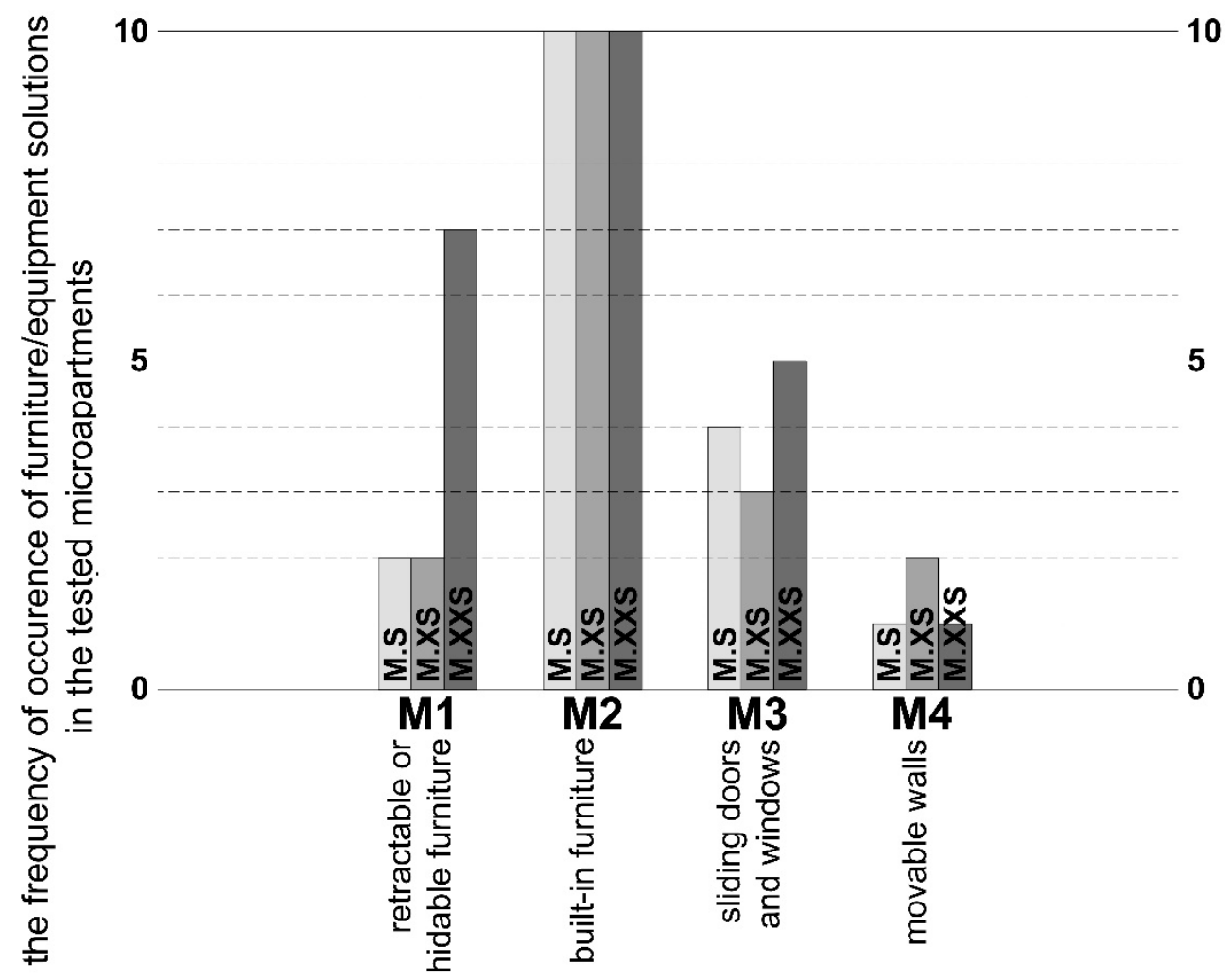

Figure 4. The frequency of occurrence of furniture/equipment solutions in the tested microapartments. 


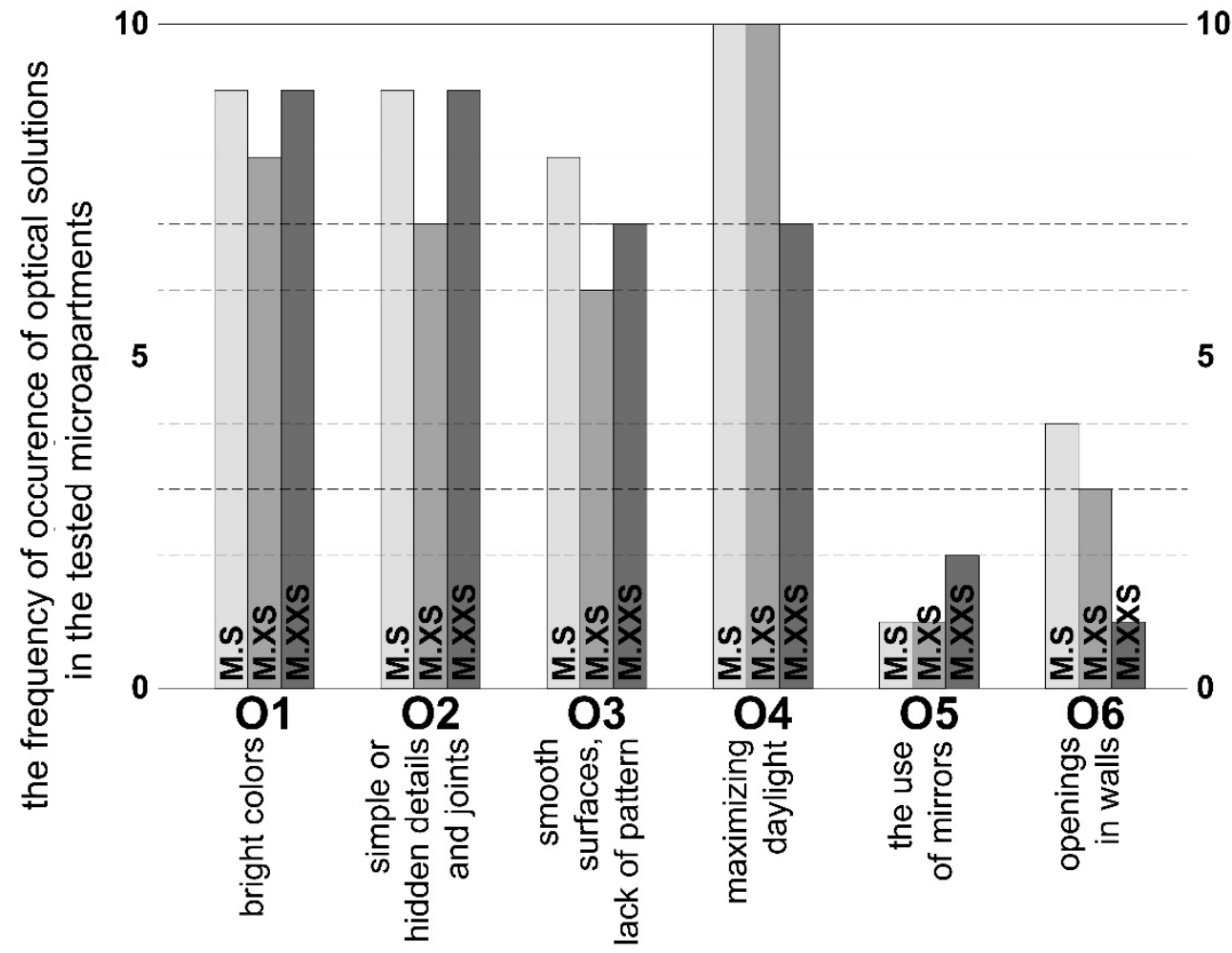

Figure 5. The frequency of occurrence of optical solutions in the tested microapartments.

The least common solutions were from the furniture and interior design group (M), here the exception was the use of built-in furniture (M2), which were present in all of the cases from this group. Typically this applied to kitchen furniture and wardrobes, and sometimes to beds. Movable walls (M4) were used once only.

\subsection{M.XS}

In units from the M.XS group, spatial solutions $(\mathrm{P})$ were the most popular. The most common solution was designing an interior with simple geometry (P4) and the avoidance of walls in favor of a different form of partitioning spaces with different functions (P2). In microflats, areas with different functions were separated from each other using built-in furniture, the shape of the space, or level differences.

The second-most popular group were functional solutions (F): the reduction of the number of rooms (F1), reducing room size (F2), and combining room functions (F4). In the case of combining functions, the most popular solution involved combining the living room with the kitchen and dining area. Uncommon combinations were also found, such as combining the vestibule with the shower (M.XS.4 Mieszkanie na Tamce) and introducing elements of the bathroom into the kitchen (M.XS.9 Mini Studio et Pans de Bois and M.XS.10 Hermes City Plaza Student Housing).

In this group, optical solutions proved to be slightly less popular-the maximum use of daylight (O4), bright colors (O1), and simple or hidden details (O2). Furniture and interior design solutions (M) were used the most rarely. Built-in furniture (M2) was the exception here, as it appeared in every case studied (this was typically kitchen furniture and wardrobes, but there was also a built-in bed).

\subsection{M.XXS}

In the group with the smallest units, functional solutions (F) were the most prevalent. All units featured a reduced number (F1) and size of rooms (F2), and the combination of functions (F4) (typically the bathroom was the only isolated space). All units featured the combining of a living room with a kitchen or dining space, and there were also interesting 
combinations of a vestibule with a workstation (M.XXS.8) or a living room with a wardrobe and laundry area, and of a kitchen with a vestibule (M.XXS.4).

Other arrangement solutions were less rarely used in this group. Among spatial solutions (P), it was popular to have no walls and isolate spaces in a different way (P2), stacking functions by placing a bed on a mezzanine (P1) and using the space under other elements (P3). From among optical solutions (O), the use of bright colors (O1) and a simple or hidden detail $(\mathrm{O} 2)$ predominated, in addition to the avoidance of patterns and the use of smooth surfaces (O3), and the maximum possible use of daylight (O4).

Furniture and equipment solutions (M) were relatively the least popular in this group. The exception here, as in the other groups, was the use of built-in furniture (kitchens and wardrobes), and in one case (M.XXS.9) all furniture was designed as built-in. In many cases, built-in-furniture (M2) was also retractable or hidden (M1). Half of the investigated cases from this group featured sliding doors (M3) (all led to bathrooms).

\section{Discussion and Conclusions}

This paper presents a study of 30 residential units with a floor area lower than $35 \mathrm{~m}^{2}$, which were independent and intended for either permanent or temporary residence and was built over the past fifteen years in several large European cities in OECD member states.

Based on the analyses conducted, it was observed that the most frequently used methods of arranging such minimal residential spaces were from the functional $(\mathrm{F})$ and spatial $(\mathrm{P})$ groups. One could also observe a tendency wherein the smaller the unit, the greater the frequency of applying methods from the functional group $(\mathrm{F})$, while spatial group solutions $(\mathrm{P})$ were more often used in larger units (Figures 6 and 7 ).

100

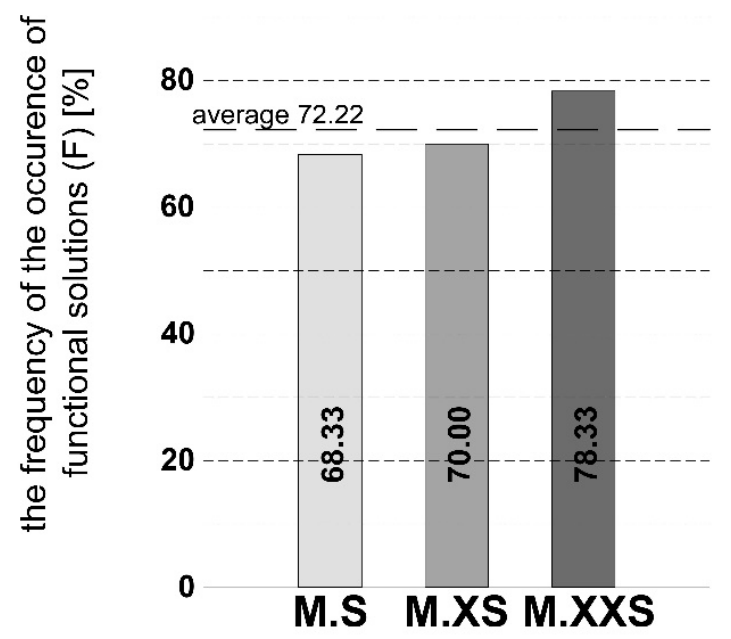

tested Group

Figure 6. The frequency of the occurrence of functional solutions.

Even though decisions on functional solutions must typically be made very early, already during the stage of formulating the functional program, they were used very often. This was most probably caused by their potentially high effectiveness. For instance, forgoing certain functions (F1) or combining them (F4) eliminates entire spaces from the functional program, which can produce significant usable floor area savings. The effectiveness of functional solutions can also be confirmed by the fact that these were the solutions applied in units with the most beneficial ratio of the residential area to total floor area. Combining functions (F4) was observed to be popular not only in small residential spaces but also in larger flats or houses. For many years, it has been a standard to combine the living room with the kitchen and dining area (and not just in small apartments). In 
the cases under study, more atypical function combinations could be observed, such as relocating portions of the bathroom function to other spaces (a shower in a vestibule, a washbasin, and a kitchen sink) or arranging a study in the vestibule. Such functional combinations can be risky and not always acceptable by users. However, in highly specific types of interiors such as microunits, especially those for a single resident, they can be justified. Among spatial solutions (P), one of the most popular procedures was function stacking (P1) by placing a bed on a mezzanine, which confirmed the findings of earlier studies [22,23].

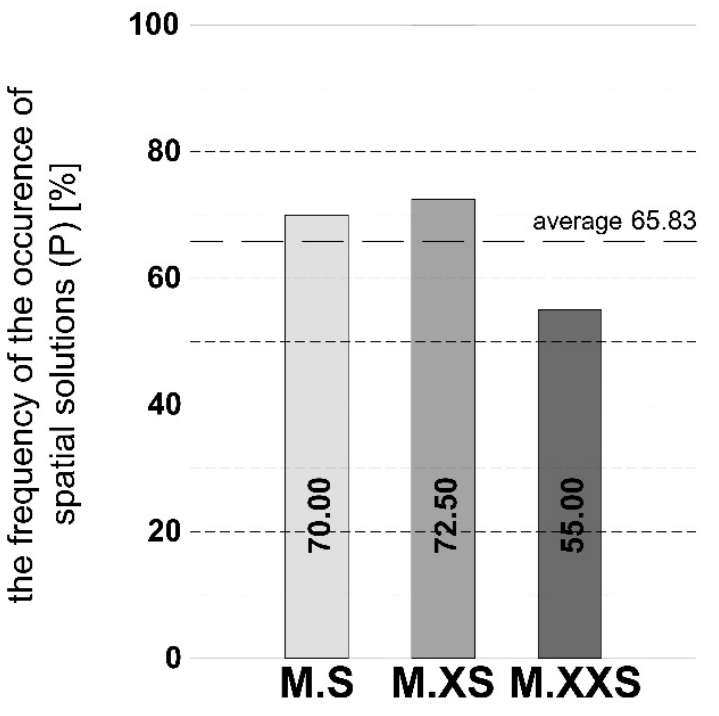

tested Group

Figure 7. The frequency of the occurrence of spatial solutions.

The most rarely used methods of arranging a minimal residential space (in all size groups) were furniture and interior design solutions (M) (Figure 8). The low popularity of solutions from this group can stem from the fact that they can be relatively expensive (e.g., hidden or retractable furniture-M1), troublesome to use (movable walls-M4), or produce little in the way of floor area savings (sliding windows or doors-M3). In addition, in the smallest of apartments, typically the only space to be isolated is the bathroom, and thus the entire space only has one door and how they open will have a minimum impact on the interior's design. The exception in this group is built-in furniture (M2), which was present in all of the cases studied. Built-in furniture is a relatively popular and well-known solution, which has been successfully used even in apartments with greater floor areas for a long time. Thøgersen [24] argued that furniture in microapartments should be light and movable, while this study shows that the most popular furniture in a microapartment is of the built-in type, and thus impossible to move. The difference in findings can be based on the fact that in the cases studied the built-in furniture typically includes the largest pieces in a flat (kitchen furniture and wardrobes) and having them built-in allows one to "hide" them from the resident's view, while smaller pieces of furniture like chairs, tables, etc., are typically freestanding.

In the case of optical solutions (Figure 9), it was observed that the most commonly used solutions were the application of bright colors (O1), hidden or simple details $(\mathrm{O} 2)$, and efforts to maximize daylight inside the unit $(\mathrm{O} 4)$, which confirms the findings of earlier studies [22,23] that concluded that residents see interiors with unobscured windows opposite the entrance as larger. Mirrors (O5) were used the least frequently (they can be troublesome in small residential spaces, e.g., they can produce optical illusions) and openings in walls between spaces (O6) (perhaps due to attempts at producing a feeling of intimacy in even the smallest flats). The group of optical solutions is the most affected by 
the designer's / client's taste or current fashion (e.g., bright colors (O1), simple or hidden details (O2), or smooth surfaces without patterns (O3)) (Figure 5).

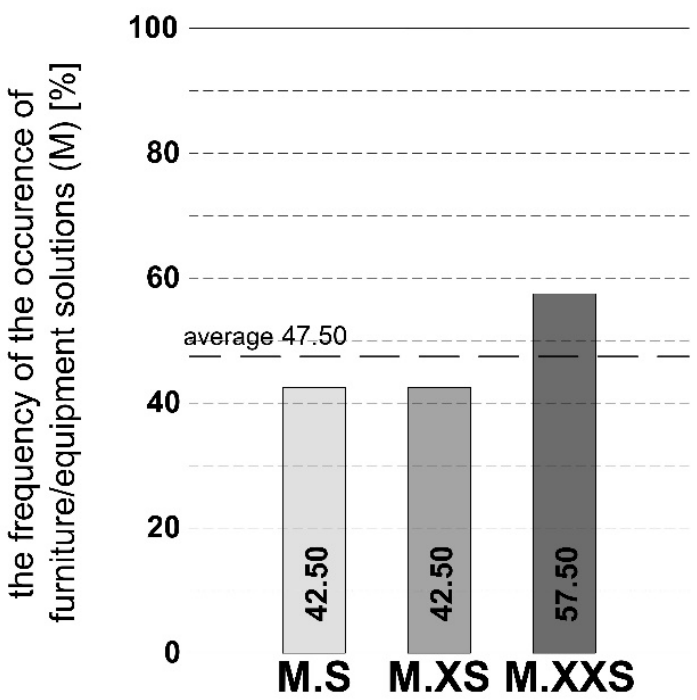

tested Group

Figure 8. The frequency of the occurrence of furniture/equipment solutions.

100

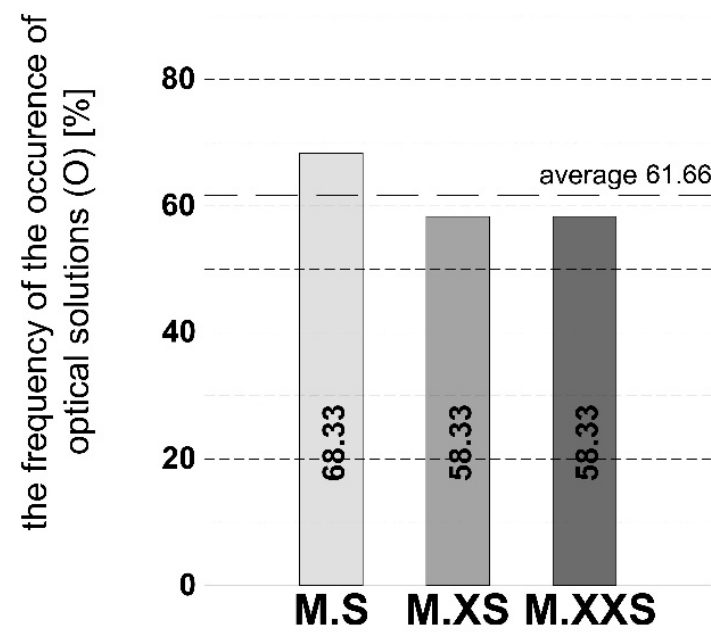

tested Group

Figure 9. The frequency of the occurrence of optical solutions.

As the cities expand and housing prices increase, microapartments can become a convenient housing alternative for people choosing to live in the city center and willing to sacrifice the size of the apartment for other advantages $[3,10,20]$,. In addition microapartments fit into the idea of sustainable development-e.g., smaller apartments reduce the carbon footprint (lower heating or cooling, less construction materials) $[3,5,10,17]$, or savings connected with a location in city centers (lower infrastructure costs, reducing the commute to the centers) $[5,10,16]$. Therefore it is crucial to learn about good ways of designing such apartments, so that reducing their size does not reduce the quality of life.

Based on the analyses presented in the study, it was concluded that microflats can take on a diverse range of forms and have a very rich functional program, which depends on the user, location, and primary function. There are a great many ways in which microunits can be designed. The manner of arrangement of a minimal residential space should be 
adapted to the building under design and approved by or tailored to the user. However, it can be observed that when extremely small microflats are concerned, the best arrangement solutions are those from the functional (F) and spatial group (P) (Figures 2, 3, 6 and 7). More decorative solutions, such as color, material (the optical solutions group- $\mathrm{O}$ ), or furniture/equipment (M) (Figures 4, 5, 8 and 9), play a secondary role. They can supplement other solutions, they can improve occupant wellbeing, but are less impactful when a microunit interior is well-designed. The key learning for the architects and interior designers is that the best effects in microunit design can be achieved by performing a comprehensive analysis of external conditions and user needs, which will allow for the introduction of bold and sometimes non-standard functional solutions. Further research in this field will explore the acceptance of proposed interior solutions by potential residents.

Author Contributions: Conceptualization, B.E.G. and A.S.; methodology, B.E.G. and A.S.; software, A.S.; validation, B.E.G. and A.S.; formal analysis, B.E.G. and A.S.; investigation, B.E.G. and A.S.; resources, B.E.G.; data curation, A.S.; writing-original draft preparation, B.E.G. and A.S.; writingreview and editing, B.E.G. and A.S.; visualization, A.S.; supervision, B.E.G.; project administration, B.E.G. and A.S.; All authors have read and agreed to the published version of the manuscript.

Funding: This research received no external funding.

Institutional Review Board Statement: Not applicable.

Informed Consent Statement: Not applicable.

Conflicts of Interest: The authors declare no conflict of interest.

\section{Appendix A}

Table A1. Plan schemes-original work based on the sources given.

\section{M.S. MICROFLAT GROUP}

M.S.1 Geneva Flat by Freaks Architects, Geneva, Switzerland, 2014
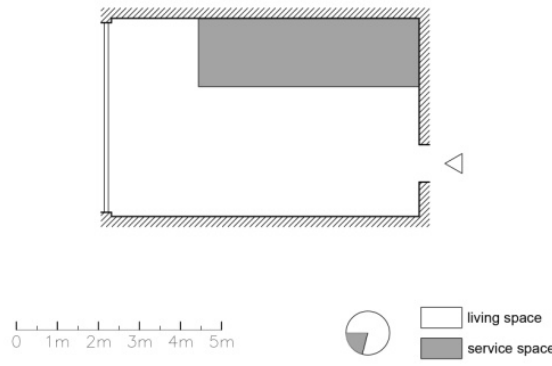

M.S.2 Apartment C by SCHEMAA, Paris, France, 2014
This unit was designed for a single person and to enable sporadic accommodation for a second person and two children. Ancillary spaces (bathroom, toilet, wardrobe, and kitchen) were grouped into a single functional block that occupies around a third of the unit's space, leaving the rest free. All the walls and the ceiling in the flat are white, and the floor was left darker. The glass wall that separates the bedroom from the kitchen does not block sunlight [32].

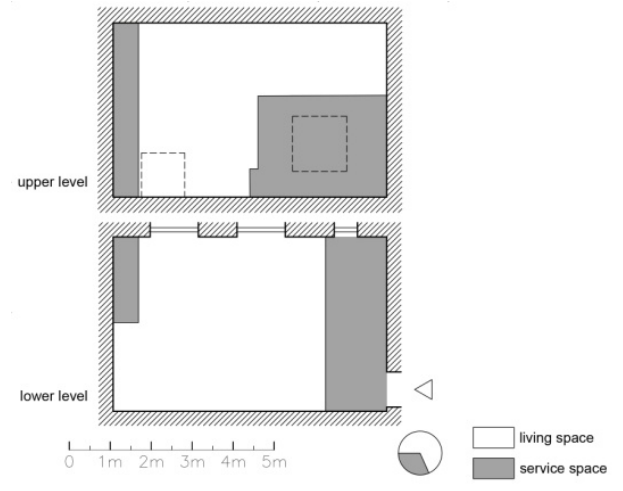

This unit is located in an attic space and has two levels. The lower level acts as a large multifunctional room with a kitchen and bathroom, while the upper level, whose floor-to-ceiling height is lower than the standard for the story, was used as a bedroom and wardrobe. The interior is bright and complemented with wooden furniture in a bright tone, small colorful elements (e.g., stools) act as accents [33]. 
Table A1. Cont.

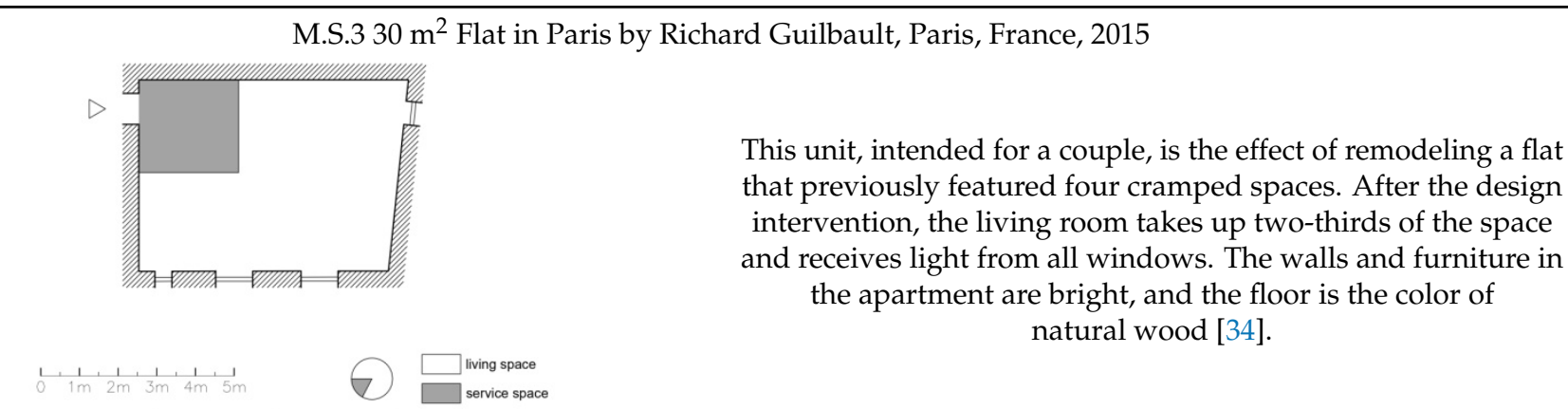

M.S.4 Casa Da Porteira, AF Arquitectos, Lisboa, Portugal, 2015

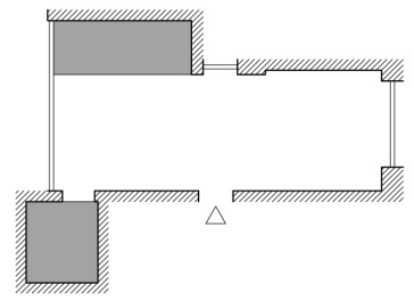

This flat is located on the roof of a building from the 1960s. The small space was divided into two parts. The main space acts as a living room with a kitchen that can be sectioned off. Nearby, behind a furniture partition, on a platform, there is the bedroom [35]

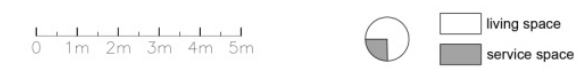

M.S.5 Długi Lokal by Mili Młodzi Ludzie, Poznań, Poland, 2014

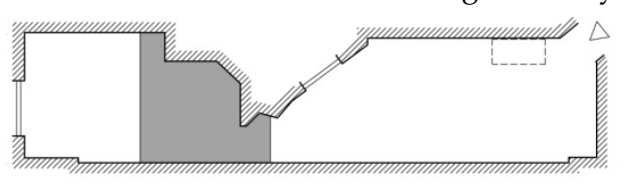

This unit has been designed for a couple in the attic of a townhouse. This space has atypical dimensions-it is very long and narrows in the center, leading to a division into two functional sections-a day zone near the entrance and a bedroom zone on the other side (Figure A1) [36,37].

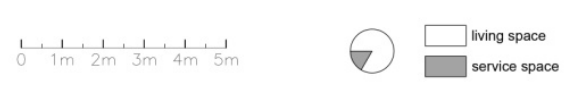

M.S.6 100 m3 by MYCC, Madrid, Spain, 2012

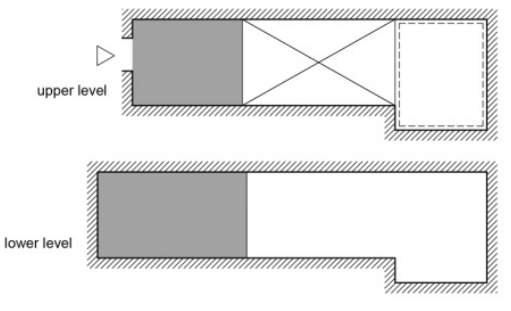

This Madrid unit, intended for one person, is located in an atypical space with a varied height and has access only to one roof window. Instead of a classical room division, it features a system of platforms and steps that define spaces with different functions and allow for free movement between them. The lack of walls between each of the apartment's zones means that sunlight is not blocked by anything [38]. 
Table A1. Cont.

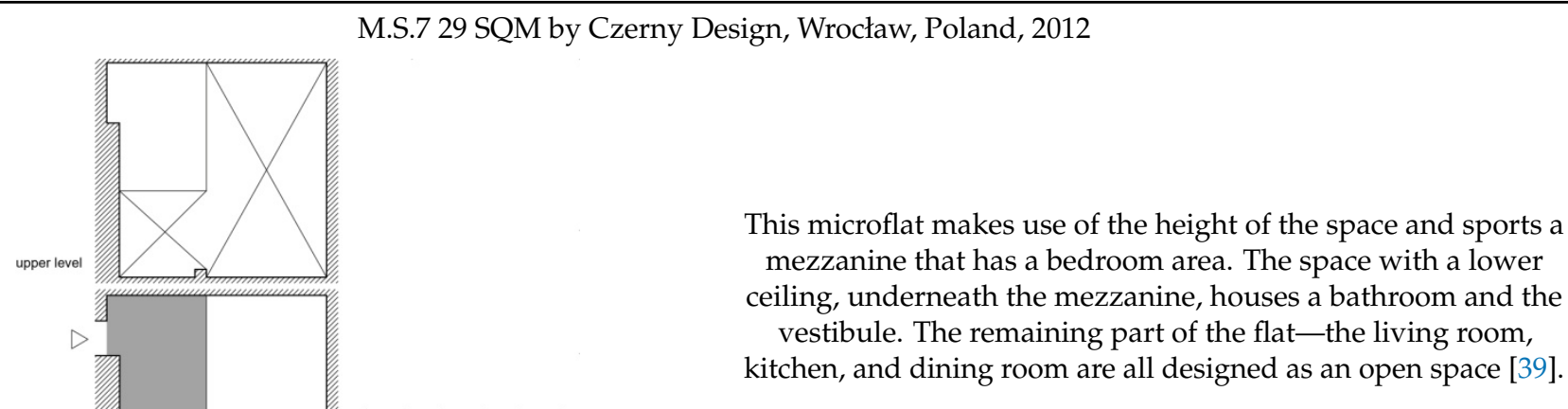

This microflat makes use of the height of the space and sports a mezzanine that has a bedroom area. The space with a lower vestibule. The remaining part of the flat-the living room,

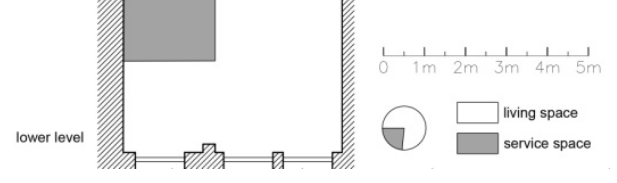

M.S.8 Batipin Flat by Studio Wok, Milan, Italy, 2015

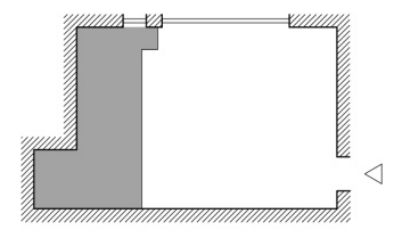

This flat, intended for a couple and located in Milan, was designed so as to leave as much space as possible in the main room so that it can be used for various functions. The primary space has plyboard walls on two sides, in which there are beds, the doors to the bathroom and kitchen, cabinets, and utilities [40].

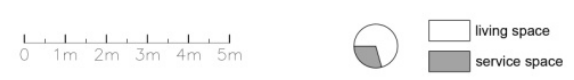

M.S.9 Air B'n'P by Position Collective, Budapest, Hungary, 2015

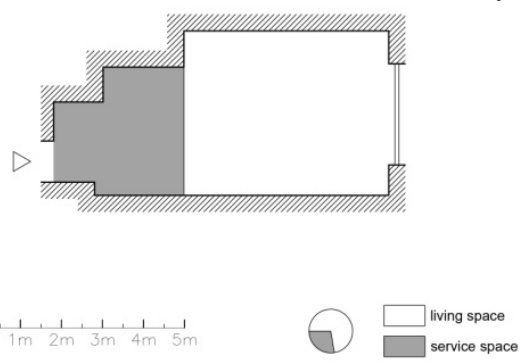

This single-space apartment was designed for a short-term lease for two persons. The only space sectioned off with walls is the bathroom, which is located beside the entrance. The remaining space acts as a living room with a bed. The central part of the

flat consists of a multi-purpose piece of furniture from plyboard-it includes a bed, cabinets, and a portion of the kitchen counter and shelves. The visually delicate partition between the sleeping area and the dining and living area is an openwork mesh screen [41].

M.S.10 Mieszkanie Piotra by Mili Młodzi Ludzie, Poznań, Poland, 2013

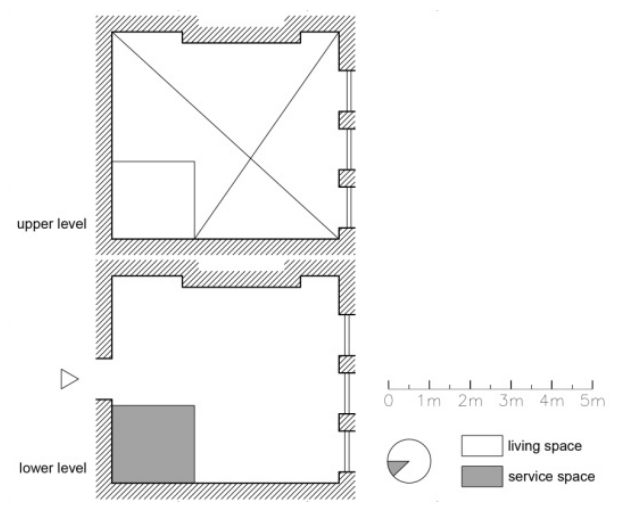

This unit, located in the attic of a townhouse, was intended for a single person. The bed was placed on a mezzanine above the bathroom, and the remaining residential space remained an open living room with a kitchen. The entire flat is in white color and crossed by black lines. All furniture and appliances-a desk, a television set, the kitchen-are hidden behind white cabinet fronts [42]. 
Table A1. Cont.

\section{M.XS. MICROFLAT GROUP}

M.XS.1 Biobombastic, elii, Madrid, Spain, 2015
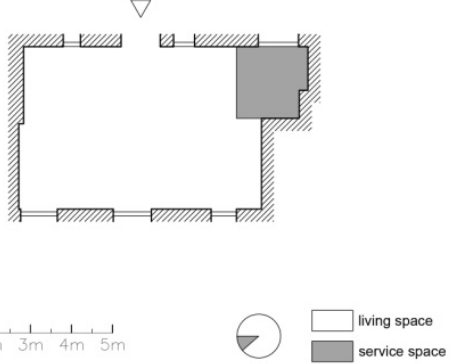

M.XS.2 Studio Li, Anne Rolland Architecture, Paris, France, 2014
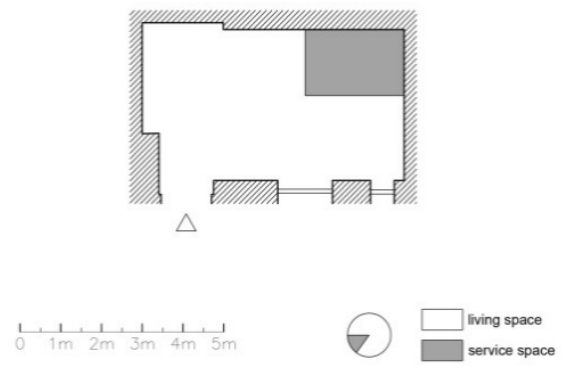

M.XS.3 Mieszkanie na Tamce, Jakub Szczęsny, Warsaw, Poland, 2009

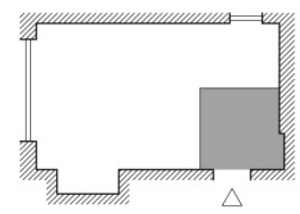

This unit was designed for a divorced man who uses it as a place to meet with his son and, on occasion, as a weekend flat. The kitchen was designed in the form of a small niche in the central portion of the space. A movable wall allows for forming a place to eat or to completely enclose and hide the kitchen. In the bathroom, due to its small dimensions, there is only a toilet and sink, while the shower is atypically placed in the hallway.

(Figure A2) [45,46]

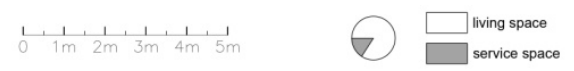

M.XS.4 Microapartament Moabit, Paola Bagna \& John Paul Coss, Berlin, Germany, 2015
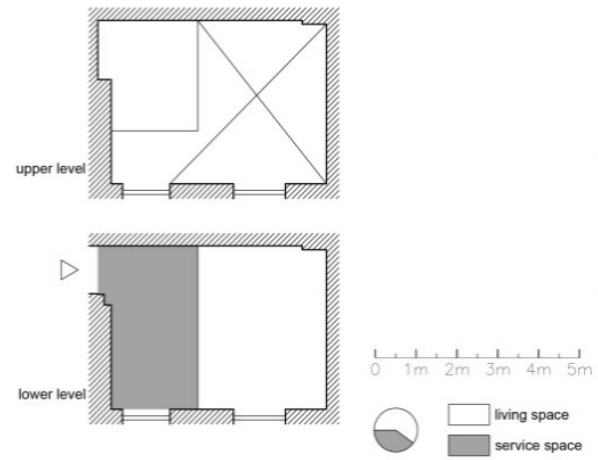

This unit was designed as 'a box in a box'. The box in question is a minimally sized bathroom, whose external walls were used as fixtures for other functions (kitchen, wardrobes, a place to sleep), freeing up the space around it. The walls and ceilings in this interior are white, and the floor and furniture partitions that surround the bathroom are the color of natural wood [47]. 
Table A1. Cont.

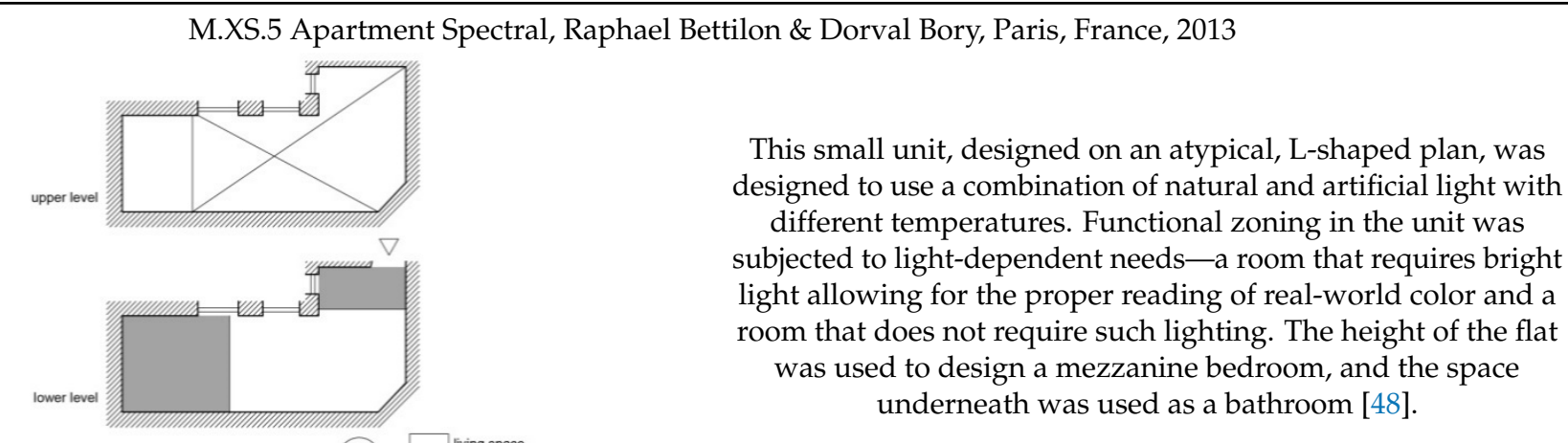

M.XS.6 Studio 18.9 m² $^{2}$ Konrad Urbanowicz, Wrocław, Poland, 2016

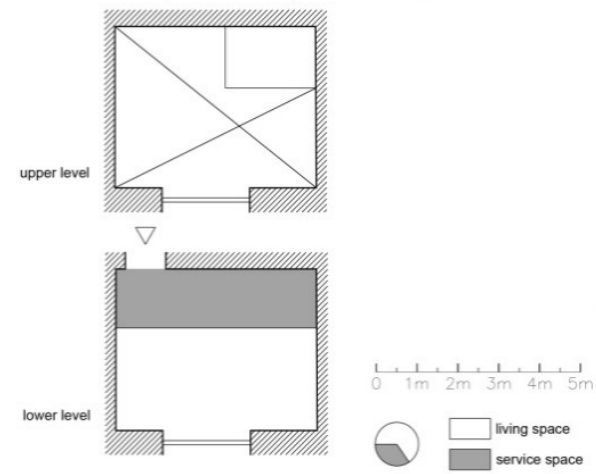

M.XS.7 Apartment AB, AB Rogers, Design, London, United Kingdom, 2017

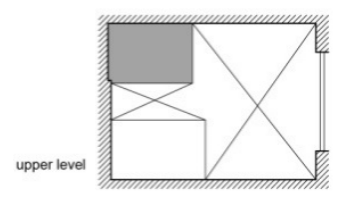

\begin{abstract}
This single-space apartment in a Wrocław townhouse was clearly divided into two functional strips-a strip of ancillary spaces beside the entrance, and an open residential daytime strop beside the window. The kitchen zone was partially sectioned off using a semi-transparent glass panel. The sleeping area is located on a mezzanine above the bathroom [49].
\end{abstract}
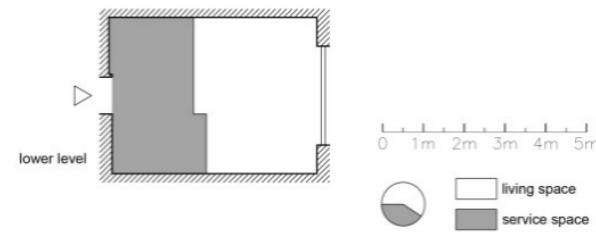

This unit, designed for a student, has been divided into two parts. The entrance area features a grouping of ancillary spaces and a bed and storage space on a mezzanine above them. This freed up space in the remaining part of the unit. Bright colors predominate in the apartment-white and light wood-yet one of the walls was painted an intense red [50].

M.XS.8 Sophia Apartment, BlackHaus, Cracow, Poland, 2017

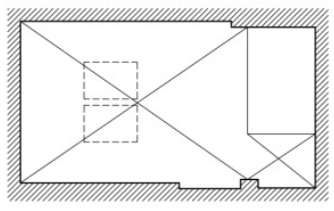

This flat is located in the attic of a townhouse and is designed for one person. The place under the steep roof was used as a

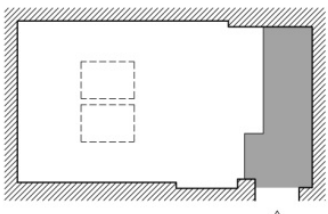
mezzanine with a sleeping area, under which is a bathroom and small vestibule. The remaining part of the flat has an open plan [51]. 
Table A1. Cont.

M.XS.9 Sato StudioKoti, Innovarch, Helsinki (Vantaa), Finland, 2017
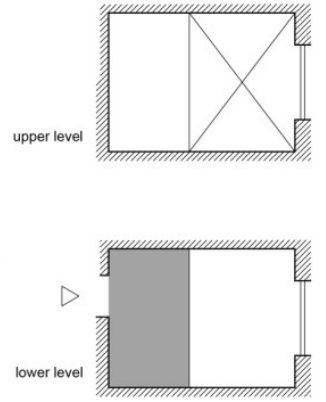

$\frac{1}{0}, \frac{1}{1 m} \cdot \frac{1}{2 m}, 1,1,1,5$

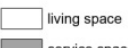

M.XS.10 Hermes City Plaza Student Housing, Standard Studio, Rotterdam, The Netherlands, 2017

The flats by StudioKoti have significant height, which was used to arrange a bed on a mezzanine, while under it there is an entrance hall with a kitchen and bathroom. The flats also have large windows and balconies [52,53].

These student units were designed in a former office building in Rotterdam's downtown. Every student unit came fully furnished and has its own bathroom and kitchen. The considerable floor-to-ceiling height allowed for designing beds suspended from the ceiling. The bed can be reached by a set of stairs that doubles as a wardrobe and shelves [54]

lower level
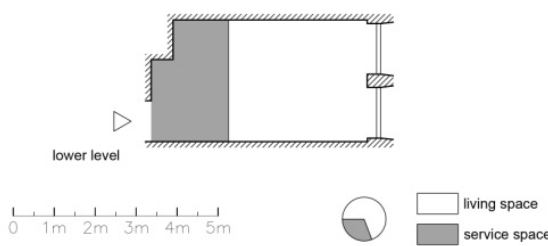

M.XXS. MICROFLAT GROUP

M.XXS.1 Bien Vivre Dans, Julie Nabucet, Marc Baillargeon, Paris, France, 2011

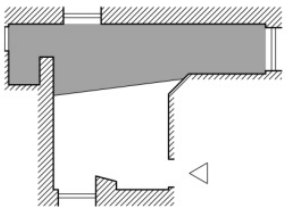

This unit was designed in a space that used to be a part of a larger flat and was previously used as a bathroom. The new residential space is intended for a student. It features a platform that zones the unit into a living and an ancillary area (a kitchen, bathroom, and wardrobe), while also serving as a space where the bed is hidden during the day [55].

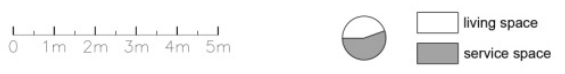

M.XXS.2 Romain, Paris Attic Studio, Paris, France, 2016

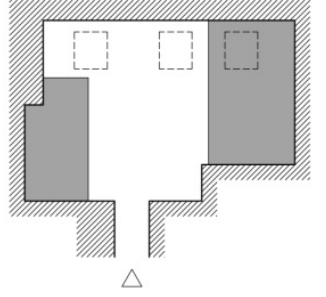

This attic unit effectively uses space under a steep roof. Places too low to use act as storage spaces and wardrobes. Placing the

kitchen on a platform has allowed for hiding the bed underneath it. The wall that separates the kitchen from the room is openwork and blocks neither the view nor access to light [56].

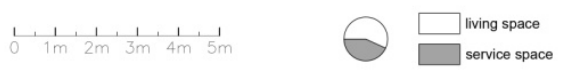


Table A1. Cont.

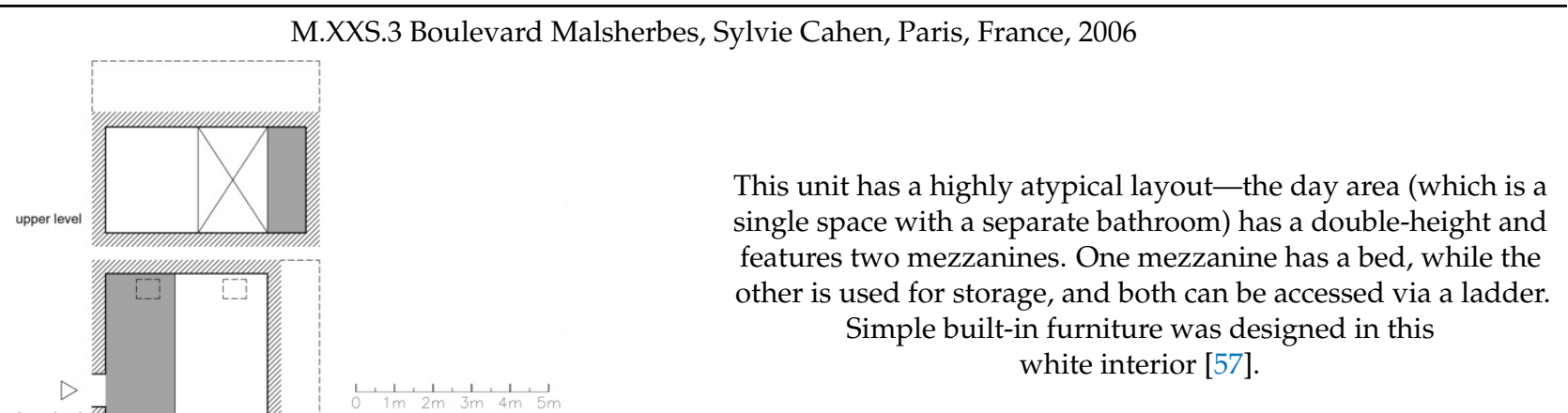

This unit has a highly atypical layout - the day area (which is a single space with a separate bathroom) has a double-height and features two mezzanines. One mezzanine has a bed, while the Simple built-in furniture was designed in this white interior [57].

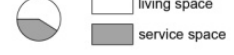

M.XXS.4 $13 \mathrm{~m}^{2}$, Szymon Hanczar, Wrocław, Poland, 2014

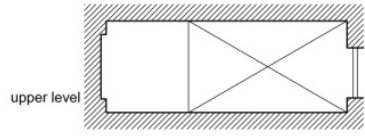

This unit makes use of space's considerable height and offers a bed placed on a mezzanine. Underneath this mezzanine is a bathroom and kitchen. The remaining part of the unit, located

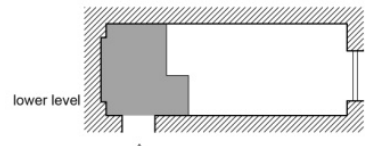
closest to the window, is fully open and acts as a living room. Bright colors predominate in this unit (white and natural light wood), supplemented with black accents (ladder, chairs, bicycle on the wall) (Figure A3) [58,59].

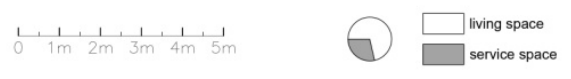

M.XXS.5 Apt. 911, Starter I, AP Szczepaniak, Wrocław, Poland, 2013

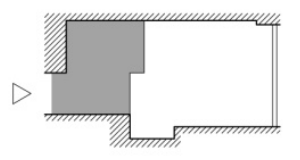

This unit is located in a former University staff hotel. The entrance section features a grouping of ancillary spaces, while the kitchen is located in a recess in a wall. The remaining space

of the unit is a multipurpose room with a folded bed. The interior was designed in bright colors (white and light wood), supplemented by a blue color accent on the walls and in kitchen
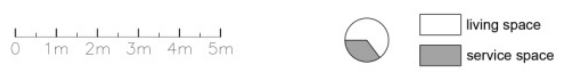
furniture [60].

M.XXS.6 Rue Lourmel, Sylvie Cahen, Paris, France, 2016
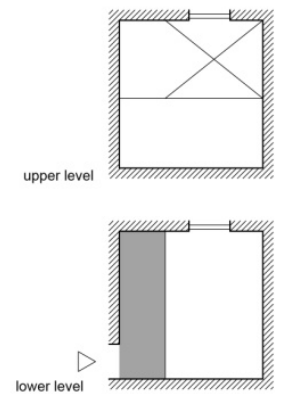

This microunit acts as a weekend flat for two people. The lower level has an open day zone with a bathroom, while the mezzanine features a place to sleep. The furniture in this unit is primarily built-in. The color of the interior is predominantly white, except wooden floors [61]. 
Table A1. Cont.

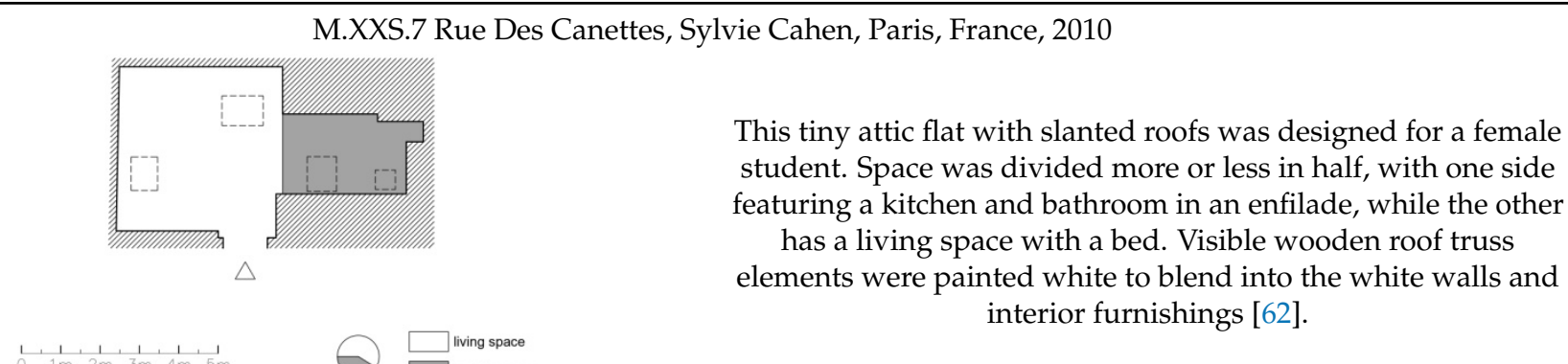

M.XXS.8 The Lux Pod, Studio Bednarski, London, United Kingdom, 2010

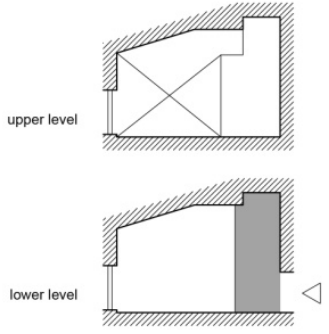

This unit was designed with a short-term lease in mind. The entry zone features ancillary rooms-a bathroom, kitchen, and a small hall, with a place to sleep located above them. The remaining space acts as a living room. A movable kitchen counter doubles as a workstation. The dark floor contrasts with bright walls and furniture $[63,64]$.

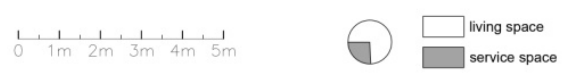

M.XXS.9 Tiny Apartment in Paris, Kitoko Studio, Paris, France, 2014

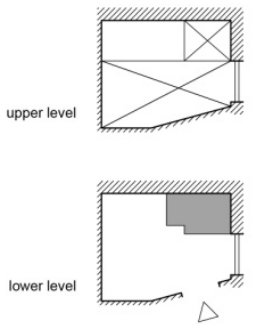

The space used to design the unit used to be a maid's quarters. Space was redesigned to meet the needs of a temporary employee. It is a single space with a functional wall that features a bathroom, a bed, a table, wardrobes, and other essential elements. The interior color is predominantly white with grey accents [65].

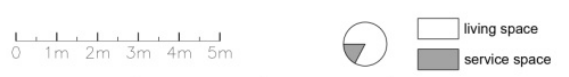

M.XXS.10 La Casa Piu Piccola di Italia, Marco Pierazzi, Rome, Italy, 2010

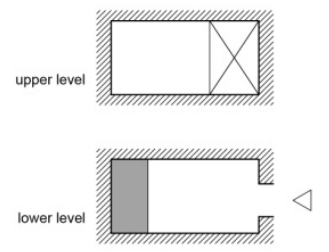

$\frac{1}{1 m} \cdot \frac{1}{2 m} \cdot \frac{1}{3 m} \cdot \frac{1}{4 m} \cdot 1 \frac{1}{2 m}$
This unit has two levels. The lower level features a living room with a kitchen, dining room, and bathroom, arranged in an enfilade. The upper level, which is accessed using stairs, features a bed. This space used to act as a main residential unit but now acts as a temporary living space. Bright furnishing elements (kitchen furniture, doors, stairs, table) contrast with original brick walls and a wooden ceiling [66]. 

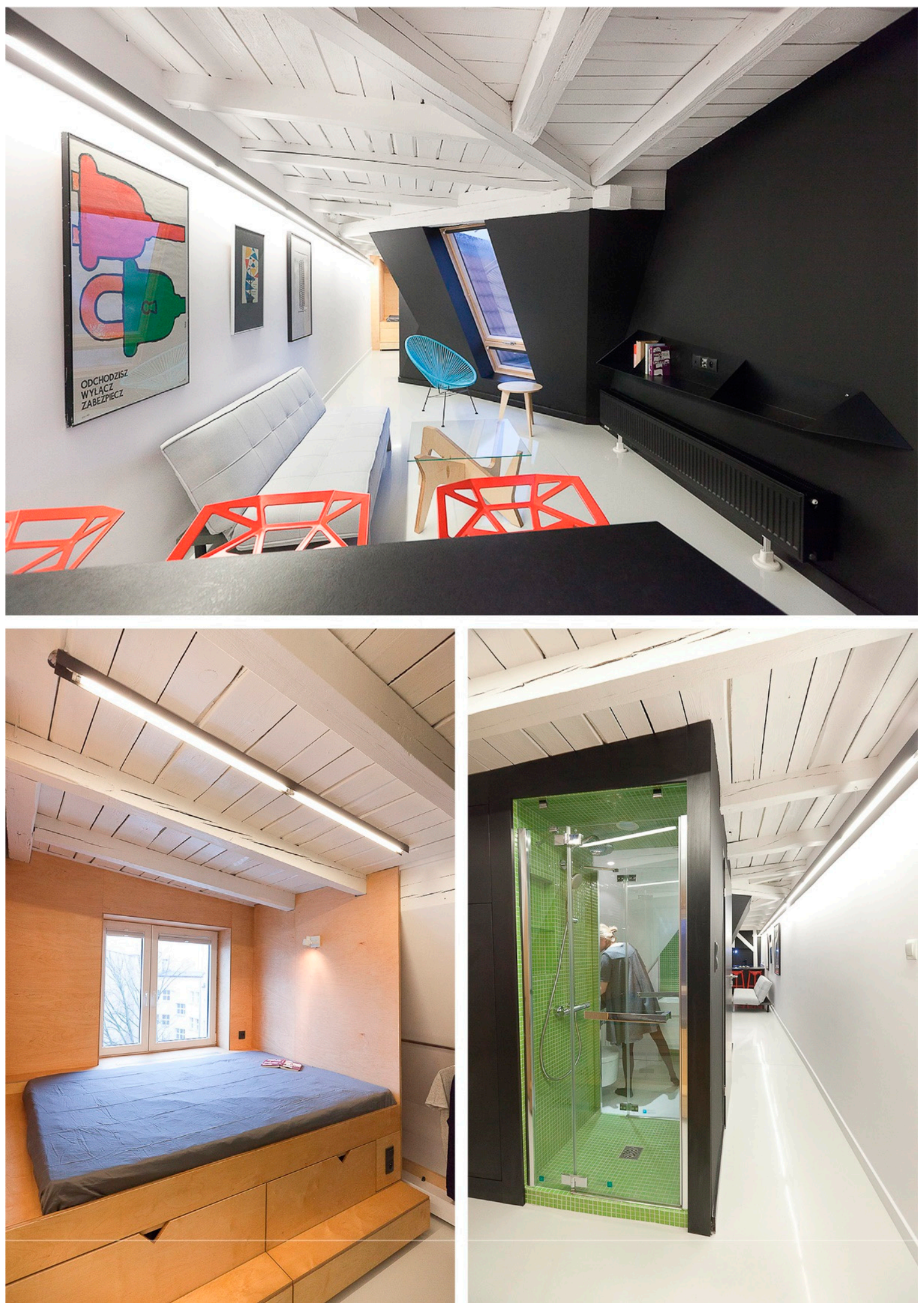

Figure A1. Interior views of M.S.5 Długi Lokal, design Mili Młodzi Ludzie, [photos PION Studio, reprodused with permission from Mili Młodzi Ludzie [31]. 

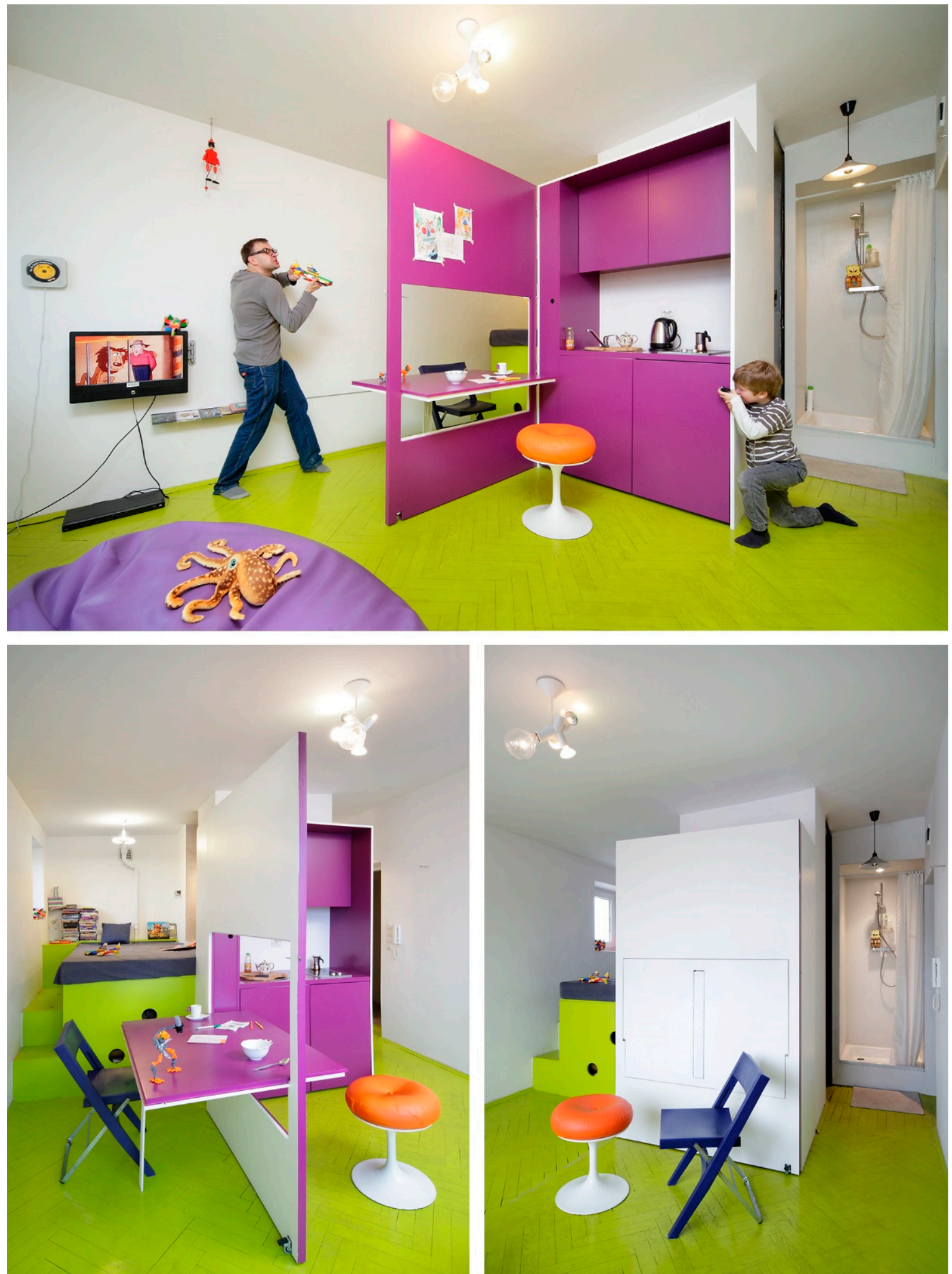

Figure A2. Interior views of M.XS.3 Mieszkanie na Tamce, design Jakub Szczęsny, [photos Radek Wojnar, styling Eva Milczarek, reprodused with permission fromJakub Szczęsny [40]. 

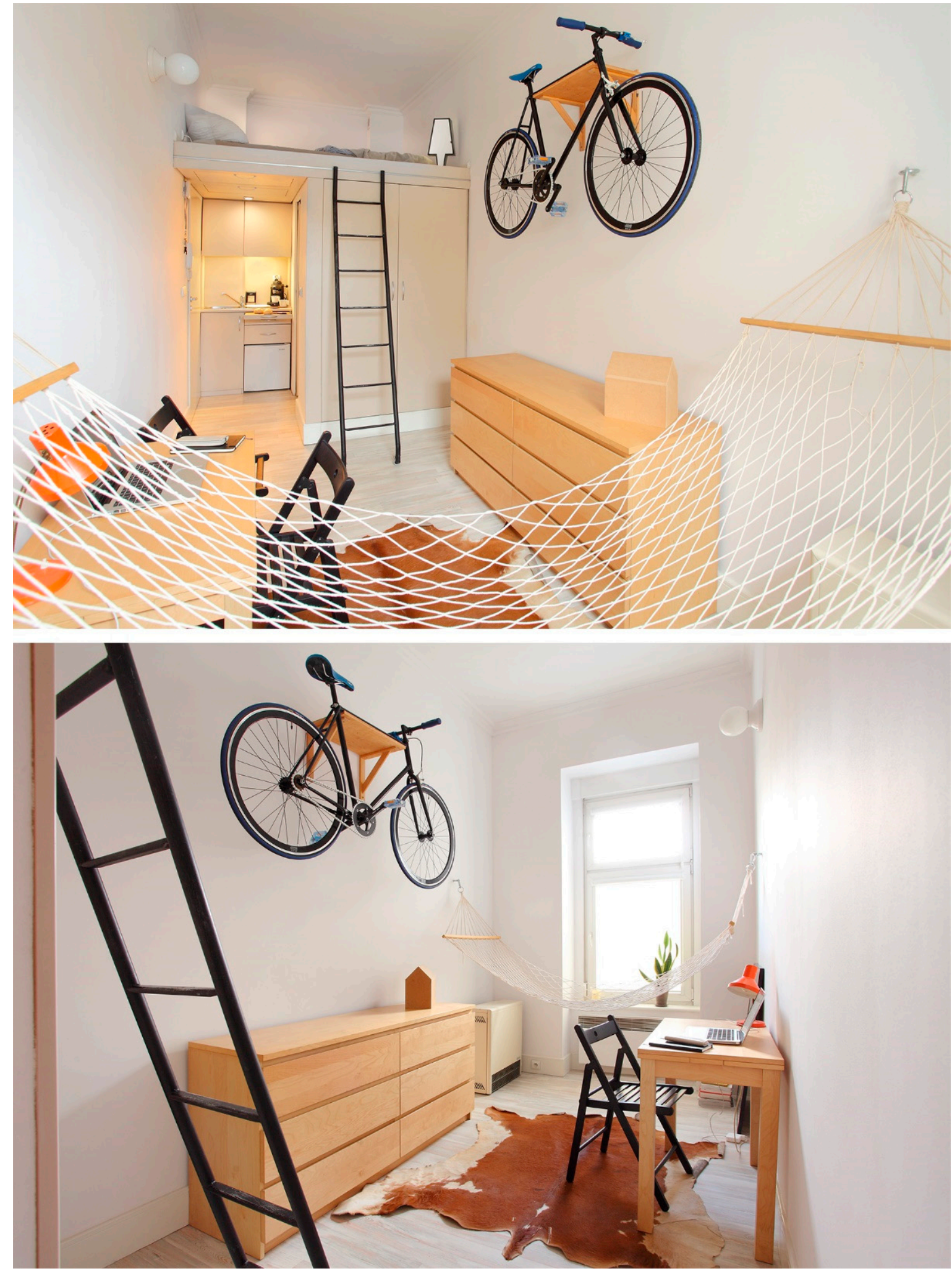

Figure A3. Interior views of M.XXS.4 $13 \mathrm{~m}^{2}$, design Szymon Hanczar, [reprodused with permission from Szymon Hanczar [52]. 
Table A2. Flats-interior design analysis, functional solutions.

\begin{tabular}{|c|c|c|c|c|c|c|}
\hline \multicolumn{7}{|c|}{ FUNCTIONAL SOLUTIONS } \\
\hline No. & F1 & F2 & F3 & F4 & F5 & F6 \\
\hline \multicolumn{7}{|c|}{$\mathrm{S}\left(25-35 \mathrm{~m}^{2}\right)$} \\
\hline M.S.1 & + & + & + & + (kitchen, dining space, living room, bedroom) & & + \\
\hline M.S.2 & + & & + & + (kitchen, dining space, living room) & + & + \\
\hline M.S.3 & + & + & & $+($ kitchen, dining space, living room) & & + \\
\hline M.S.4 & & + & + & $+($ kitchen, dining space, living room) & & \\
\hline M.S.5 & + & + & + & $+($ kitchen, dining space, living room) & & \\
\hline M.S.6 & + & + & + & & & \\
\hline M.S.7 & + & + & + & + (kitchen, dining space, living room) & & + \\
\hline M.S.8 & + & & + & + (kitchen, dining space, living room, bedroom) & + & + \\
\hline M.S.9 & + & + & & + (kitchen, dining space, living room, bedroom) & & \\
\hline M.S.10 & + & + & + & + (kitchen, dining space, living room) & & \\
\hline \multicolumn{7}{|c|}{$X S\left(15-25 \mathrm{~m}^{2}\right)$} \\
\hline M.XS.1 & + & + & + & + (kitchen, dining space, living room) & + & \\
\hline M.XS.2 & & & + & $+($ dining space, study) & & \\
\hline M.XS.3 & + & + & + & $+($ kitchen, dining space, study) (vestibule, shower) & + & + \\
\hline M.XS.4 & + & + & + & & & + \\
\hline M.XS.5 & + & + & + & + (kitchen, dining space, living room) (bathroom, wardrobe) & & \\
\hline M.XS.6 & + & + & + & + (living room, dining space, workstation) & & \\
\hline M.XS.7 & + & + & & $+($ kitchen, dining space, living room) & & + \\
\hline M.XS.8 & + & + & + & $+($ kitchen, dining space, living room) & & \\
\hline M.XS.9 & + & + & + & $+($ kitchen, vestibule) & & + \\
\hline M.XS.10 & + & + & & + (kitchen, dining space, living room) (bathroom, kitchen) & & + \\
\hline \multicolumn{7}{|c|}{$\mathrm{XXS}\left(<15 \mathrm{~m}^{2}\right)$} \\
\hline M.XXS.1 & + & + & + & + (kitchen, dining space) (living room, bedroom, study) & + & \\
\hline M.XXS.2 & + & + & + & + (living room, bedroom, study, dining space) & + & \\
\hline M.XXS.3 & + & + & & + (living room, dining space, kitchen) & & \\
\hline M.XXS.4 & + & + & + & + (kitchen, vestibule), (living room, wardrobe) & & + \\
\hline M.XXS.5 & + & + & & + (living room, bedroom, kitchen, dining space) & + & \\
\hline M.XXS.6 & + & + & + & + (living room, kitchen, dining space) & & \\
\hline M.XXS.7 & + & + & + & + (living room, bedroom) & & + \\
\hline M.XXS.8 & + & + & + & + (living room, dining space, kitchen) (vestibule, study) & + & \\
\hline M.XXS.9 & + & + & + & + (living room, dining space, kitchen, bedroom, wardrobe) & + & + \\
\hline M.XXS.10 & + & + & + & + (living room, dining space, kitchen) (bedroom, living room) & + & \\
\hline
\end{tabular}

Table A3. Flats-interior design analysis, spatial solutions.

\begin{tabular}{|c|c|c|c|c|}
\hline \multicolumn{5}{|c|}{ SPATIAL SOLUTIONS } \\
\hline No. & P1 & P2 & P3 & P4 \\
\hline \multicolumn{5}{|c|}{$\mathrm{S}\left(25-35 \mathrm{~m}^{2}\right)$} \\
\hline M.S.1 & \multirow{5}{*}{$\begin{array}{l}+ \text { (bed and wardrobe } \\
\text { on a mezzanine) }\end{array}$} & + (glass) & + (space under the bed) & + \\
\hline M.S.2 & & + (low openwork partitions) & + (space under the stairs) & + \\
\hline M.S.3 & & & $\begin{array}{l}\text { + (space under the bed and the entire } \\
\text { height of the wall) }\end{array}$ & + \\
\hline M.S.4 & & + (wardrobe, stairs) & & + \\
\hline M.S.5 & & + (shape of the space) & $\begin{array}{c}+ \text { (space under the bed and } \\
\text { the sloped roof) }\end{array}$ & \\
\hline M.S.6 & + (numerous levels) & + (various levels) & + (numerous levels) & \\
\hline M.S.7 & + (bed on a mezzanine) & + (shape of the space) & + (space under the stairs) & + \\
\hline M.S.8 & & & + (space along the entire wall height) & + \\
\hline M.S.9 & & + (openwork mesh) & + (space under the stairs) & + \\
\hline M.S.10 & + (bed on a mezzanine) & & + (space along the entire wall height) & + \\
\hline
\end{tabular}


Table A3. Cont.

\begin{tabular}{|c|c|c|c|c|}
\hline \multicolumn{5}{|c|}{ SPATIAL SOLUTIONS } \\
\hline No. & P1 & P2 & P3 & P4 \\
\hline \multicolumn{5}{|c|}{$\mathrm{XS}\left(15-25 \mathrm{~m}^{2}\right)$} \\
\hline M.XS.1 & & & & + \\
\hline M.XS.2 & & + (level difference, furniture as partition) & $+($ space under the bed $)$ & + \\
\hline M.XS.3 & & + (level difference, furniture as partition) & + (space under the bed) & + \\
\hline M.XS.4 & & + (shape of the space) & & + \\
\hline M.XS.5 & + (bed on a mezzanine) & + (shape of the space, stairs) & & + \\
\hline M.XS.6 & + (bed on a mezzanine) & $+($ glass panel) & & + \\
\hline M.XS.7 & + (bed on a mezzanine) & $\begin{array}{c}+ \text { (shape of the space, furniture } \\
\text { as partition) }\end{array}$ & $\begin{array}{c}\text { + (space under the bed, under the stairs, } \\
\text { above the bathroom) }\end{array}$ & + \\
\hline M.XS.8 & + (bed on a mezzanine) & & & + \\
\hline M.XS.9 & + (bed on a mezzanine) & + (openwork partition) & + (space under the stairs) & + \\
\hline M.XS.10 & + (bed on a mezzanine) & + (furniture as a partition) & + (space under the stairs) & + \\
\hline \multicolumn{5}{|c|}{$\mathrm{XXS}\left(<15 \mathrm{~m}^{2}\right)$} \\
\hline M. XXS.1 & & + (level difference, furniture as partition) & + (space under the kitchen) & \\
\hline M.XXS.2 & & + (level difference, furniture as partition) & + (space under the kitchen) & + \\
\hline M.XXS.3 & + (bed on a mezzanine) & & & \\
\hline M.XXS.4 & + (bed on a mezzanine) & $\begin{array}{c}+ \text { (shape of the space furniture } \\
\text { as a partition) }\end{array}$ & $\begin{array}{c}+ \text { (bathroom, kitchen, wardrobe under } \\
\text { the mezzanine) }\end{array}$ & + \\
\hline M.XXS.5 & & & & \\
\hline M.XXS.6 & + (bed on a mezzanine) & & & \\
\hline M.XXS.7 & & $\begin{array}{c}+ \text { (openwork partition, furniture } \\
\text { as partition) }\end{array}$ & & \\
\hline M.XXS.8 & $+($ bed on a mezzanine $)$ & & + (bathroom under the mezzanine) & \\
\hline M.XXS.9 & $+($ bed on a mezzanine) & + (furniture as a partition) & $\begin{array}{c}+ \text { (an entire wall that can be vertically } \\
\text { used for various elements) }\end{array}$ & + \\
\hline M.XXS.10 & + (bed on a mezzanine) & + (furniture as a partition) & $\begin{array}{c}+ \text { (bathroom and wardrobes under the } \\
\text { stairs and mezzanine) }\end{array}$ & + \\
\hline
\end{tabular}

Table A4. Flats-interior design analysis, furniture, and equipment solutions.

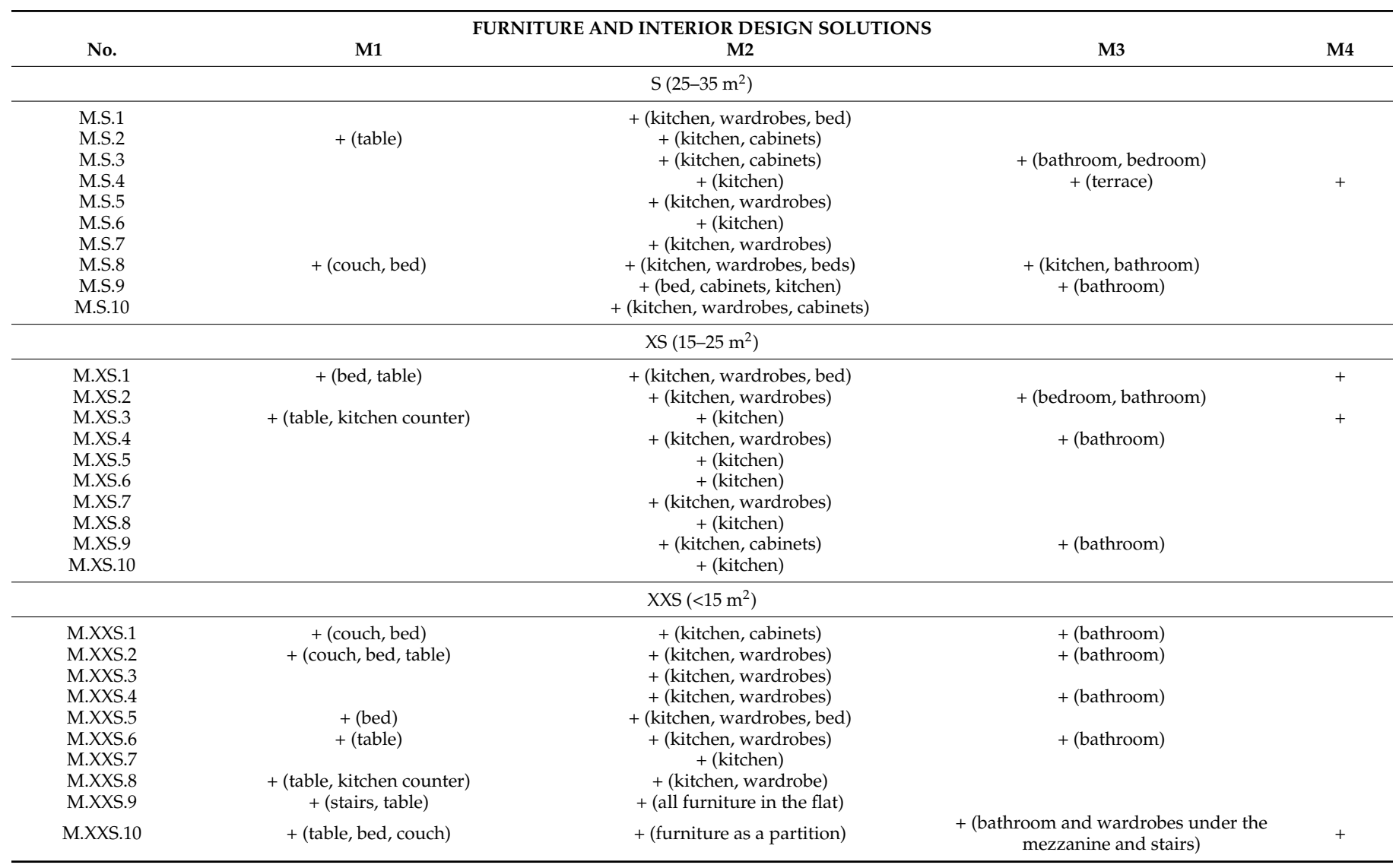


Table A5. Flats—interior design analysis, optical solutions.

\begin{tabular}{|c|c|c|c|c|c|c|}
\hline \multicolumn{7}{|c|}{ OPTICAL SOLUTIONS } \\
\hline No. & O1 & $\mathrm{O} 2$ & O3 & $\mathrm{O} 4$ & O5 & O6 \\
\hline \multicolumn{7}{|c|}{$\mathrm{S}\left(25-35 \mathrm{~m}^{2}\right)$} \\
\hline M.S.1 & + & + & + & + & & \\
\hline M.S.2 & + & + & + & + & + & + (between the wardrobe and bedroom) \\
\hline M.S.3 & + & + & + & + & & \\
\hline M.S.4 & + & + & + & + & & \\
\hline M.S.5 & & + & + & + & & + (between the bathroom and bedroom) \\
\hline M.S.6 & + & + & + & + & & + (between the bathroom and toilet, bedroom, kitchen) \\
\hline M.S.7 & + & & & + & & \\
\hline M.S.8 & + & + & + & + & & \\
\hline M.S.9 & + & + & + & + & & $\begin{array}{l}+ \text { (between the bathroom and the room, the sleeping area in the } \\
\text { living room-frosted glass) }\end{array}$ \\
\hline M.S.10 & + & + & & + & & \\
\hline \multicolumn{7}{|c|}{$X S\left(15-25 \mathrm{~m}^{2}\right)$} \\
\hline M.XS.1 & + & + & + & + & & \\
\hline M.XS.2 & + & & & + & & + (between the bedroom and the living room) \\
\hline M.XS.3 & & + & + & + & & + (between the bathroom and the bedroom) \\
\hline M.XS.4 & + & + & + & + & + & $\begin{array}{l}+ \text { (between the bathroom and the bedroom-opening in the } \\
\text { mezzanine's floor) }\end{array}$ \\
\hline M.XS.5 & + & + & + & + & & \\
\hline M.XS.6 & & & & + & & \\
\hline M.XS.7 & + & + & + & + & & \\
\hline M.XS.8 & + & & & + & & \\
\hline M.XS.9 & + & + & & + & & \\
\hline M.XS.10 & + & + & + & + & & \\
\hline \multicolumn{7}{|c|}{$\mathrm{XXS}\left(<15 \mathrm{~m}^{2}\right)$} \\
\hline M.XXS.1 & & + & + & + & & \\
\hline M.XXS.2 & + & + & & + & & \\
\hline M.XXS.3 & + & + & + & & & \\
\hline M.XXS.4 & + & + & + & + & & \\
\hline M.XXS.5 & + & + & + & + & & \\
\hline M.XXS.6 & + & + & + & + & & \\
\hline M.XXS.7 & + & + & + & & + & $\begin{array}{c}+ \text { (between the bathroom and kitchen, the kitchen and } \\
\text { the living room) }\end{array}$ \\
\hline M.XXS.8 & + & + & + & + & + & \\
\hline M.XXS.9 & + & + & & + & & \\
\hline M.XXS.10 & + & & & & & \\
\hline
\end{tabular}

\section{References}

1. Białko, M. Potrzeby mieszkaniowe współczesnych społeczeństw. Przestrzeń i FORMA 2013, 19, 65-80.

2. Breit, S.; Gürtler, D. Microliving-Urbanes Wohnen im 21. Jahrhundert; GDI Gottlieb Duttweiler Institute: Rüschlikon, Switzerland, 2018.

3. Shore, Z. The Case of Micro-Apartment Housing in Growing Urban Centers. Master's Thesis, Science in Real Estate Development, Massachusetts Institute of Technolog, Cambridge, MA, USA, 2014. Available online: https://dspace.mit.edu/handle/1721.1/87610 (accessed on 15 November 2020).

4. Geffner, T. Towards a Smaller Housing Paradigm: A Literature Review of Accessory Dwelling Units and Micro Apartments. Ph.D. Thesis, University Honors, Pittsburgh, PA, USA, 2018. [CrossRef]

5. Infranca, J. Housing Changing Households: Regulatory Challenges for Micro-Units and Accessory Dwelling Units. Stanf. Law Policy Rev. 2014, 25, 53-89. Available online: https:/ / ssrn.com/abstract=2339136 (accessed on 15 November 2020).

6. Doll, J. Is Living Alone the New Shacking Up? The Atlantic. 2012. Available online: https://www.theatlantic.com/national/ archive/2012/02/living-alone-new-shacking/332191/ (accessed on 20 February 2021).

7. Marešová, P.; Mohelská, H.; Kuča, K. Economics aspects of Ageing Population. Proc. Econ. Finance 2015, 23, 534-538. [CrossRef]

8. Mossakowska, M.; Więcek, A.; Błędowski, P. Aspekty Medyczne, Psychologiczne, Socjologiczne i Ekonomiczne Starzenia się Ludzi w Polsce; Termedia Wydawnictwa Medyczne Poznań: Poznań, Poland, 2012; ISBN 978-83-62138-81-4.

9. Czyńska, M. Dom Polski-Meblościanka z Pikasami; Wydawnictwo Czarne: Wołowiec, Poland, 2017.

10. Infranca, J. Spaces for Sharing: Micro Units Amid the Shift from Ownership to Access. Fordham Urb. Law J. 2016, 43, 1, Suffolk University Law School Research Paper No. 15-38. Available online: https:/ /ssrn.com/abstract=2678072 (accessed on 15 November 2020).

11. Murray, C. Minimalist Living: Is Minimalism Just a Fad? Or Can It Really Help You Solve All Your Financial Problems? Money under 30. 2020. Available online: https:/ / www.moneyunder30.com/minimalist-living (accessed on 10 January 2021). 
12. Southern Cross University. Going Green. 2019. Available online: https:// online.scu.edu.au/blog/going-green/ (accessed on 31 January 2021).

13. Osborne, R. Best Practices for Urban Coliving Communities. Master's Thesis, Science in Architecture, University of Nebraska, Lincoln, NE, USA, 2018. Available online: http:/ / digitalcommons.unl.edu/arch_id_theses/16 (accessed on 18 November 2021).

14. Urban Land Institute. The Macro View on Micro Units. Washington. 2014. Available online: http://uli.org/wp-content/uploads/ ULI-Documents/MicroUnit_full_rev_2015.pdf (accessed on 3 January 2021).

15. Cohen, M.J. New Conceptions of Sufficient Home Size in High-Income Countries: Are We Approaching a Sustainable Consumption Transition? Hous. Theory Soc. 2021, 38, 173-203. [CrossRef]

16. Withers, D. Looking for a Home: How Micro-Housing Can Help California? Gold. Gate Univ. Environ. Law J. 2012, 6, 125-152.

17. Wilson, A.; Boehland, J. Small Is Beautiful: U.S. House Size, Resource Use, and the Environment. J. Ind. Ecol. 2005, 9, 277-287. [CrossRef]

18. Urist, J. The Health Risks of Small Apartments. Living in Tiny Spaces Can Cause Psychological Problems. The Atlantic. 2013. Available online: https:/ / www.theatlantic.com/health/archive/2013/12/the-health-risks-of-small-apartments / 282150/ (accessed on 25 September 2018).

19. Twardoch, A. Mniej znaczy więcej, czy mniej za więcej. Przestrzenne, społeczne i psychologiczne ujęcie kwestii mikroapartamentów. Teka Komisji Urbanistyki i Architektury PAN Oddział w Krakowie 2017, XLV, 107-122.

20. Clinton, E. Micro-living: Why occupants choose to live in very small dwellings? Aust. Plan. 2018, 55, 189-197. [CrossRef]

21. Gabbe, C.J. Looking through the Lens of Size: Land Use Regulations and Micro-Apartments in San Francisco. Cityscape 2015, 17, 223-238. [CrossRef]

22. Fisher-Gewirtzman, D. The Association between Perceived Density in Minimum Apartments and Spatial Openness Index Three-Dimensional Visual Analysis. Environ. Plan. B Plan. Des. 2017, 44, 764-795. [CrossRef]

23. Fisher-Gewirtzman, D. The Impact of Alternative Interior Configurations on the Perceived Density of Micro Apartments. J. Archit. Plan. Res. 2017, 34, 336-358.

24. Thøgersen, K. Designing Furniture for Small Spaces, in Connection with Human Wellbeing. 2017. Available online: https://www.semanticscholar.org/paper/Designing-furniture-for-small-spaces\%2C-in-connection-Th\%C3\%B8gersen/0f952 5cf9f5095c1fc74a16481d0ec8dc95d147e (accessed on 17 September 2021).

25. OECD. Functional Urban Areas by Country. Available online: https://www.oecd.org/regional/regional-statistics/functionalurban-areas.htm (accessed on 23 August 2021).

26. Yin, R.K. Case Study Research and Applications: Design and Methods; Sage: Los Angeles, CA, USA, 2018.

27. Parikh, A. Making the Most of Small Spaces; Gardner Books: Eastbourne, UK, 1994; ISBN 978-18-50295-74-7.

28. Schleifer, S. Small Apartments; Taschen: Köln, Germany, 2005.

29. Susanka, S.; Obolensky, K. The Not So Big House: A Blueprint for the Way We Really Live; Taunton Press, Inc.: Newtown, CT, USA, 1998.

30. Susanka, S. Not So Big Solutions for Your Home; Taunton Press, Inc.: Newtown, CT, USA, 2002.

31. Susanka, S. More Not So Big Solutions for Your Home; Taunton Press, Inc.: Newtown, CT, USA, 2010.

32. Freaks Architecture. Genève. Available online: https://freaksarchitecture.com/portfolio/geneve (accessed on 17 December 2020).

33. Schemaa. Appartement C. Available online: https://schemaa.fr/page-projet-appartement-c (accessed on 18 December 2020).

34. ArchDaily. $30 \mathrm{~m}^{2}$ Flat in Paris/Richard Guilbault. Available online: https:/ /www.archdaily.com/623445/30m2-flat-in-parisrichard-guilbault (accessed on 18 December 2020).

35. AF Arquitectos. Casa da Porteira. Available online: http://www.afarquitectos.com/ (accessed on 23 August 2021).

36. Mili Młodzi Ludzie. Długi Lokal. Available online: http:/ / milimlodziludzie.com/galeria-2-10/ (accessed on 13 February 2021).

37. Moczulski, Lech. E-Mail Messages to Author, 2021. 8 February 2021.

38. Mycc.es Architecture Office. $100 \mathrm{~m}^{3}$ (Almirante). Available online: http://www.mycc.es/work100m3.html (accessed on 20 December 2020).

39. Czerny Design. 29 SQM. Available online: https://czernydesign.pl/portfolio_page/29-sqm/ (accessed on 30 August 2021).

40. Studio Wok. Studio Wok—Batipin Flat. 2015. Available online: https://studiowok.com/project/batipin-flat-4/ (accessed on 18 December 2020).

41. Position-Concept. AirB'n'P Apartment. Your Home Away from Home in Budapest. Available online: https://position-concept. com/portfolio/airbnp-2/ (accessed on 13 February 2021).

42. Mili Młodzi Ludzie. Mieszkanie Piotra. Available online: http://milimlodziludzie.com/galeria-2-7/ (accessed on 20 December 2020).

43. Elii.es. 077 Biobombastic Muchas Casas en Una. Available online: http://elii.es/portfolio/biombombastic/ (accessed on 20 December 2020).

44. Anne Rolland Architecte. Studio Li. De la Cuisine au Studio. Available online: http:/ / www.annerollandarchitecte.fr/projets/ logement/studio-li.php (accessed on 20 December 2020).

45. Szcz. Tamka Apartment. Available online: www.szcz.com.pl/portfolio_page/tamka (accessed on 27 December 2020).

46. Szczesny, Jakub. E-Mail Messages to Author, 2021. 8 February 2021. 
47. Paola Bagna Architect. Micro Apartment Moabit Berlin. 2015. Available online: http://paolabagna.com/refurbishment-microapartament-berlin-moabit (accessed on 20 December 2020).

48. NicolasDorvalBory. Appartement Spectral. Available online: http://nicolasdorvalbory.fr/project:appartement-spectral (accessed on 20 December 2020).

49. Urbanowicz, Konrad. E-Mail Messages to Author, 2018. 4-8 June 2018.

50. AB Rogers Design. Compact Living. Available online: http://www.abrogers.com/portfolio/ compact-living (accessed on 14 December 2020).

51. BlackHaus Karol Ciepliński Architekt. Sophia Apartment. Available online: https://blackhaus.co/project/ophia-apartment (accessed on 30 August 2021).

52. MTV Uutiset 40 vuotta. Voisitko Asua 15 Neliössä? Minikoti on Niin Suosittu, Etteivät Lähellekään Kaikki Halukkaat saa Asuntoa. 16 November. Available online: https:/ / www.mtvuutiset.fi/artikkeli/voisitko-asua-15-neliossa-minikoti-on-niinsuosittu-etteivat-lahellekaan-kaikki-halukkaat-saa-asuntoa/7165398\#gs.9j5h5o (accessed on 29 August 2021).

53. SATO. Available online: https://www.sato.fi/en/media/apartment-photos (accessed on 19 August 2021).

54. StandardStudio. Hermes City Plaza-The Room. Available online: https://standardstudio.nl/portfolio/hermes-city-plaza/ (accessed on 14 December 2020).

55. Julie Nabucet Architectures. Bien Vivre Dans $16 \mathrm{~m}^{2}$. Une Sale de Bains Transformée en Studio. Available online: http: / / www.julienabucet.com/portfolio/bien-vivre-dans-16m2/ (accessed on 14 December 2020).

56. Williamson, C. An Old Attic Apartment Goes Modern. 2016. Available online: https://design-milk.com/old-attic-apartmentgoes-modern/ (accessed on 20 December 2020).

57. Atelier Sylvie Cahen. Boulevard Malsherbes. Available online: https://www.ateliersylviecahen.com/realisations/chambresbonnes / (accessed on 20 December 2020).

58. Hanczar, Szymon. E-Mail Messages to Author, 2021. 8 February 2021.

59. Mills, P. Szymon Hanczar Crams His Entire City Home Into 13 Square Meters. Available online: https://www.dezeen.com/2015 /07/18/szymon-hanczar-13-square-metre-micro-apartment-wroclaw-poland/ (accessed on 20 December 2020).

60. Starter. Starter I, Aranżacja Lokalu 11. Available online: http:/ /www.starter.net.pl/pl/p-multimedia/starter-1 (accessed on 17 December 2020).

61. Atelier Sylvie Cahen. Rue Lourmel. Available online: https://www.ateliersylviecahen.com/realisations/duplex-minimaliste/ (accessed on 20 December 2020).

62. Atelier Sylvie Cahen. Rue Des Canettes. Available online: https://www.ateliersylviecahen.com/realisations/grenier-studiofonctionnel/ (accessed on 20 December 2020).

63. Studio Bednarski Ltd. LUX POD, 38 Gloucester Road, London SW7. Available online: http:/ /www.studio-bednarski.com/LUXP. php (accessed on 25 August 2021).

64. TheLuxPod. The Lux Pod, London. Available online: http://www.theluxpod.com (accessed on 17 December 2020).

65. ArchDaily. Tiny Apartment in Paris/Kitoko Studio. Available online: https://www.archdaily.com/562119/tiny-apartment-inparis-kitoko-studio (accessed on 17 December 2020).

66. La Casa Più Piccola d'Italia. Available online: http:/ / www.lacasapiupiccoladitalia.com/ (accessed on 17 December 2020). 